\section{Special Report 84-8}

April 1984

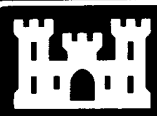

US Army Corps of Engineers

Cold Regions Research \& Engineering Laboratory

\title{
Accumulation, characterization, and stabilization of sludges for cold regions lagoons
}

R.W. Schneiter, E.J. Middlebrooks, R.S. Sletten and S.C. Reed 


\begin{tabular}{|c|c|}
\hline REPORT DOCUMENTATION PAGE & $\begin{array}{l}\text { READ INSTRUCTIONS } \\
\text { BEFORE COMPLETING FORM }\end{array}$ \\
\hline $\begin{array}{l}\text { 1. REPORT NUMBER } \\
\text { Special Report } 84-8\end{array}$ & 3. RECIPIENT'S CATALOG NUMBER \\
\hline \multirow[t]{2}{*}{$\begin{array}{l}\text { 4. TITLE (and Subtitle) } \\
\text { ACCUMULATION, CHARACTERIZATION, AND STABILIZATION } \\
\text { OF SLUDGES FOR COLD REGIONS LAGOONS }\end{array}$} & 5. TYPE OF REPORT \& PERIOD COVERED \\
\hline & 6. PERFORMING ORG. REPORT NUMBER \\
\hline $\begin{array}{l}\text { 7. AUTHOR(s) } \\
\text { R.W. Schneiter, E.J. Middlebrooks, } \\
\text { R.S. Sletten and S.C. Reed }\end{array}$ & 8. CONTRACT OR GRANT NUMBER( $(8)$ \\
\hline $\begin{array}{l}\text { 9. PERFORMING ORGANIZATION NAME AND ADDRESS } \\
\text { Utah State University, Logan, Utah, and } \\
\text { U.S. Army Cold Regions Research and Engineering } \\
\text { Laboratory, Hanover, New Hampshire } 03755\end{array}$ & $\begin{array}{l}\text { 10. PROGRAM ELEMENT, PROJECT, TASK } \\
\text { AREA \& WORK UNIT'NUMBERS }\end{array}$ \\
\hline \multirow{3}{*}{$\begin{array}{l}\text { 11. CONTROLLING OFFICE NAME AND ADDRESS } \\
\text { Office of the Chief of Engineers } \\
\text { Washington, D.C. } 20314\end{array}$} & 12. REPORT DATE \\
\hline & April 1984 \\
\hline & $\begin{array}{l}\text { 13. NUMBER OF PAGES } \\
45\end{array}$ \\
\hline \multirow[t]{2}{*}{ 14. MONITORING AGENCY NAME \& ADDRESS(If different from Controlling Office) } & $\begin{array}{l}\text { 15. SECURITY CLASS. (of this roport) } \\
\text { Unclassified }\end{array}$ \\
\hline & $\begin{array}{l}\text { 15a. DECLASSIFICATION/DOWNGRADING } \\
\text { SCHEDULE }\end{array}$ \\
\hline
\end{tabular}

\section{DISTRIBUTION STATEMENT (of this Report)}

Approved for public release; distribution unlimited.

17. DISTRIBUTION STATEMENT (of the abstract entered in Block 20, if different from Report)

18. SUPPLEMENTARY NOTES

19. KEY WORDS (Continue on reverse side if necessary and identify by block number)

Cold regions

Lagoons

Sanitary engineering

Sewage

Sludge

20. ABSTAACT (Continue an peverso stide if necesceary and fdentily by block number)

Accumulated solids associated with the operation of aerated and facultative lagoons in cold climates were investigated to determine 1) the rate and extent of solids accumulation, 2) the characteristics of the accumulated solids, 3) the potential for in situ stabilization of the accumulated solids, and 4) the effect of lime treatment upon the pathogenic population and subsequent solids drying on sand and soil beds. Accumulated sludges from the Logan and Corinne, Utah, facultative lagoons and the Palmer and Galena, Alaska, partial mix aerated lagoons were studied. The rates of accumulation, determined by in situ measurement of 


\section{Abstract (cont'd).}

the sludge layer in each lagoon, were found to vary with lagoon type and specific operational and environmental conditions. The solids characteristics, determined for samples upon collection and for samples in cold storage over time, were found to be generally comparable to those of conventional primary sludges. Sludge samples were stored for an extended period at temperatures that model winter conditions at the lagoon bottom and were periodically tested to determine if changes were occurring in basic sludge characteristics. With the exception of bacterial concentration reduction no significant changes were observed, indicating that in situ stabilization of the sludge is probably not occurring in the actual lagoons under low temperature conditions. Aerobic and anderobic digestion studies were also performed with these sludge samples and are reported elsewhere. Lime treatment of the lagoon sludges was evaluated by dosing the sludges with lime and applying the limed sludges to bench-scale sand and soil drying beds. Lime addition produced high pathogen kill. The limed sludges readily dewatered on both sand and soil beds. 


\section{PREFACE}

This report was prepared by R.W. Schneiter, graduate student, and E.J. Middlebrooks, Dean, of the College of Engineering, Utah State University, Logan, Utah, and R.S. Sletten and S.C. Reed, Environmental Engineers, of the Civil Engineering Research Branch, Experimental Engineering Division, U.S. Army Cold Regions Research and Engineering Laboratory. Funding for the research described in this report was provided by DA Project 4A762730A896, Environmental Quality for Construction and Operation of Military Facilities, Task Area T2, Pollution Abatement Systems, Work Unit 004 , Waste Treatment Techniques in Cold Climates.

The manuscript of this report was technically reviewed by J.F. Wheeler of the U.S. Environmental Protection Agency, and J.R. Bouzoun of CRREL. 


\section{CONTENTS}

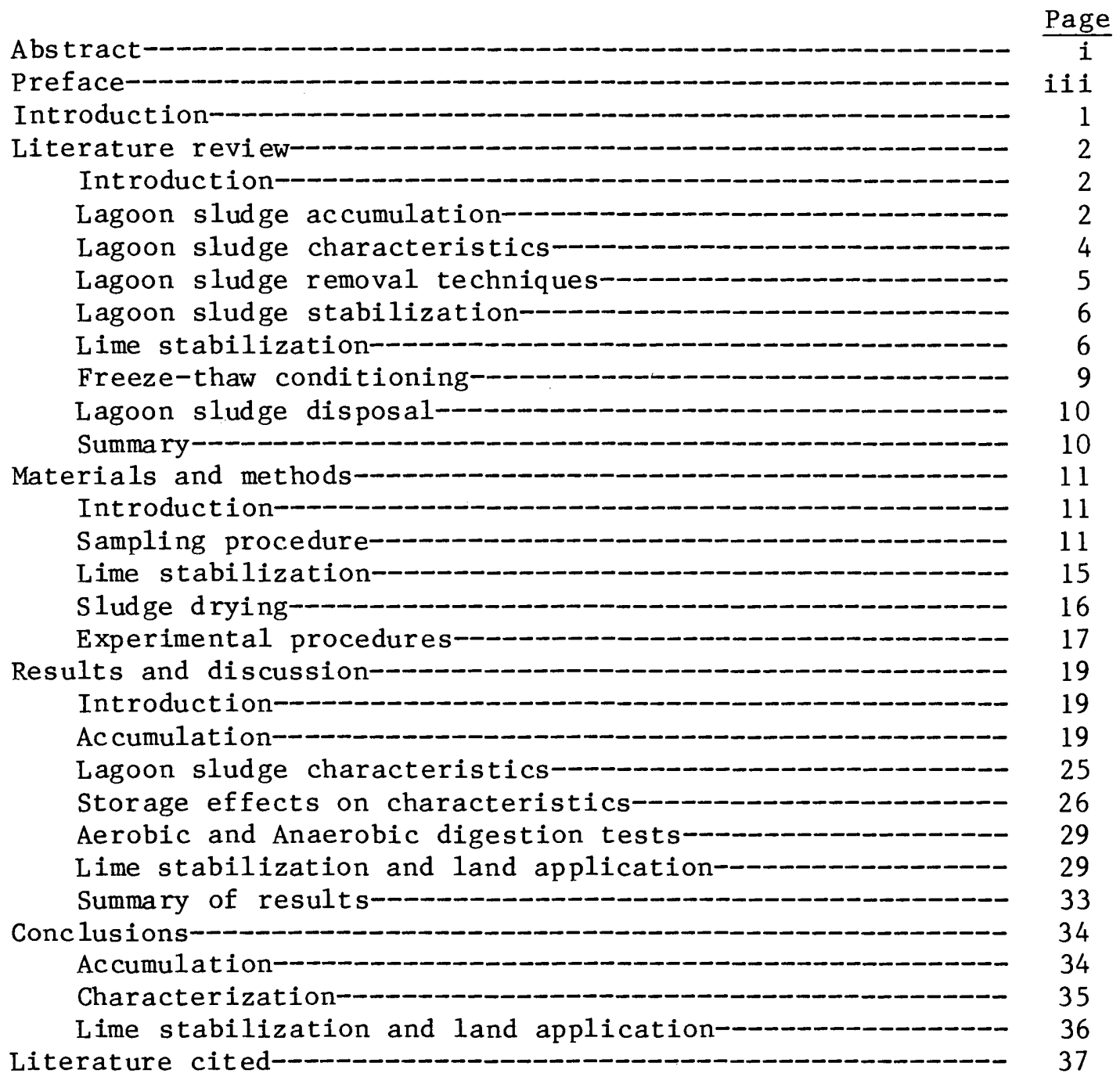

\section{ILLUSTRATIONS}

Figure

1. Total coliform bacteria reduction in lime treated wastewater at an initial $\mathrm{pH}$ of 12.0 , at $1^{\circ} \mathrm{C}$ to $15^{\circ} \mathrm{C}-\cdots$

2. Combined lime dosage versus $\mathrm{pH}$ for primary, anaerobically digested, waste activated, and septage sludges--- 8

3. Sample collection area and grid dimensions for the Logan, Utah, wastewater lagoon system-------- 12

4. Sample collection area and grid dimensions for the Corinne, Utah, wastewater lagoon system--_-_-_-_ 12

5. Sample collection area and grid dimensions for the Palmer, Alaska, wastewater lagoon system-_-_-_-_-_-_-_ 
6. Sample collection area and grid dimensions for the

Galena, Alaska, wastewater lagoon system------------- 13

7. Lagoon sludge core sampling tube--_---_---_---_--- 14

8. Schematic of the photo-electric cell used to determine accumulated sludge depth in the Palmer and Galena,

Alaska, lagoons

9. Lime stabilization apparatus-_- 16

10. Schematic diagram of a lysimeter column--_ 17

11. Sand lysimeter group-_- 18

12. Sludge depth distribution over the bottom of the Logan, Utah, lagoon system cell A2- 20

13. Sludge depth distribution over the bottom of the Corinne, Utah, lagoon system primary cel1---_-_---- 21

14. Sludge depth distribution over the bottom of the Palmer, Alaska, lagoon system aerated cell--------- 21

15. Sludge depth distribution over the bottom of the

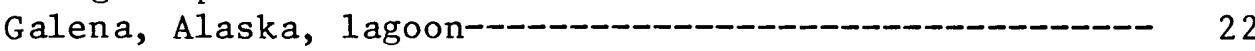

16. Palmer, Alaska, lagoon aerated cel1, drained----------- 22

17. Ratio of volatile to total solids over time for Logan lagoon---------------------------------------

18. Ratio of volatile to total solids over time for Palmer lagoon--_-_-_-_-_-_-_-_-_-_-_-_-_-_-_-_-_-_-_-_-_-_

\section{TABLES}

Table

1. Lagoon types and applications-- 3

2. Biological characteristics of lagoon sludges------- 5

3. Bacterial count reduction from lime addition to liquid municipal sludge------

4. Description of lagoon sites----

5. Lagoon siudge accumulation data summary---_-

6. Lagoon solids summary--

7. Comparison of wastewater lagoon and primary sludge characteristics---_---_--_--- 25

8. Physical characteristics of the accumulated sludges collected from the Utah and Alaska lagoons----_---- 25

9. Ratios of volatile to total solids for the Logan and Palmer lagoons-_-_-_-_-_-_-_-_-_-_-_-_-_-_-_-_-_

10. $\mathrm{Ca}(\mathrm{OH})_{2}$ dose required to raise sludge $\mathrm{pH}$ value to 12.5 and maintain the $\mathrm{pH}$ at 12.5 for 30 min-_-_-

11. Change in $\mathrm{pH}$ value with time for lime treated sludge---

12. Change in sludge thickness with time for sludges

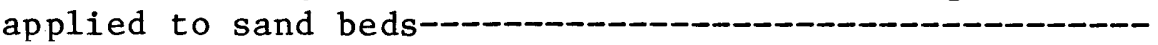

13. Change in sludge thickness with time for sludges applied to soil beds-- 32

14. Change in moisture content of lime treated sludge over time for sludges applied to sand beds--

15. Change in moisture content of lime treated sludge over time for sludges applied to soil beds-_-_-_-_-_-_-_-- 


\section{ACCUMULATION, CHARACTERIZATION, AND STABILIZATION}

OF SLUDGES FOR COLD REGIONS LAGOONS

by

R.W. Schneiter, E.J. Middlebrooks, R.S. Sletten and S.C. Reed

\section{INTRODUCTION}

Wastewater lagoons can effectively treat municipal wastewaters and can be easily operated and maintained in all climatic areas. Treatment occurs through natural biological and physical processes that, in some cases, are aided by mechanical aeration. The solids that may settle and accumulate on the lagoon bottom are typically organic and inorganic solids in the untreated wastewater entering the lagoon and the biological solids produced by the treatment process.

Lagoons operating in climates where the bottom water and sludge temperatures may exceed $19^{\circ} \mathrm{C}$ will generally not experience excessive biological sludge accumulation problems. However, where these temperatures fall below $19^{\circ} \mathrm{C}$, the solids accumulate faster than they can be digested and a net sludge buildup results (Oswald 1968). In some climatic regions sludge accumulates during cold winter months but digests sufficiently during the warmer summer months to maintain the desired balance. Unfortunately, the sludge is not always completely digested and accumulation is a function of the cycles of cold winters and warm summers. Lagoons in Anchorage, Alaska, for example, which is a relatively warm location in the cold regions, experience a maximum temperature of about 13 to $15^{\circ} \mathrm{C}$ in the benthic sludge accumulation zone for only 2 to 4 months per year. If excess sludge in sewage lagoons is accumulating, then sludge volume and characteristics require definition, and techniques for remova1, treatment, and disposal need to be developed.

The primary objective of this study was to provide information on sludge accumulation, treatment, and disposal in cold regions wastewater lagoons. This objective was achieved by:

1. Conducting a literature review encompassing lagoon design and lagoon sludge accumulation, characteristics, removal, treatment, and disposal. 
2. Evaluating the extent of sludge accumulation in selected cold climate lagoons in Alaska and Utah.

3. Characterizing sludges collected from selected cold climate lagoons.

4. Evaluating the potential for in situ sludge stabilization at 1 ow temperatures.

5. Evaluating lime treatment for sludges removed from 1 agoons.

6. Evaluating sand and soil drying beds for lagoon sludge dewatering.

The following four major phases outline the work undertaken in this study: 1) measurement of lagoon sludge accumulation, 2) lagoon sludge characterization, 3) periodic analysis of low temperature samples and digestion studies, and 4) evaluation of lime treatment and sand and soil drying of 1agoon sludges.

Field work was conducted at two multiple cell facultative lagoons in northern Utah, and two partial-mixed aerated lagoons, one in southern Alaska, the other in central Alaska. Both Alaskan lagoons were single cell units. The mechanical aeration of the Alaskan lagoons might result in some increase in the total amount of sludge deposited due to the increased capability for biological activity in the winter months as compared to an unaerated, icecovered lagoon. However, the presence of the aeration is not believed to have any significant impact on the sludge once it is deposited because of the low power levels and incomplete mixing. Therefore, the potential for digestion or stabilization of the bottom sludges should be essentially the same for facultative and partial-mix aerated lagoons as influenced by the local environmental conditions and other site-specific factors.

\section{LITERATURE REVIEW}

Introduction

Lagoon classifications describe the prevalent biological activity occurring within the pond; Table 1 summarizes the basic lagoon types and their application (Metcalf and Eddy 1979, EPA 1975).

\section{Lagoon Sludge Accumulation}

Sludge accumulates to varying degrees on the bottom of nearly all types of wastewater treatment lagoons. The deepest deposits occur near the inlet and remain until solids degradation processes or wind action, temperature inversion, or other natural phenomena (that resuspend the material) reduce the accumulation. Since low winter temperatures in colder climates inhibit 
Table 1. Lagoon types and applications (Metcalf and Eddy 1979, EPA 1975).

\begin{tabular}{|c|c|c|c|}
\hline $\begin{array}{l}\text { Type of pond or } \\
\text { pond system }\end{array}$ & $\begin{array}{l}\text { Common } \\
\text { name }\end{array}$ & $\begin{array}{l}\text { Identifying } \\
\text { characteristic }\end{array}$ & Application \\
\hline \multirow[t]{2}{*}{ Aerobic } & Oxidation pond & $\begin{array}{l}\text { Designed to maintain aerobic } \\
\text { conditions throughout the } \\
\text { liquid depth. }\end{array}$ & $\begin{array}{l}\text { Treatment of primary and secon- } \\
\text { dary effluents. }\end{array}$ \\
\hline & Polishing pond & $\begin{array}{l}\text { Similar to low-rate aerobic } \\
\text { ponds but very lightly loaded. }\end{array}$ & $\begin{array}{l}\text { Used for polishing (upgrading) } \\
\text { effluents from conventional sec- } \\
\text { ondary treatment processes. }\end{array}$ \\
\hline $\begin{array}{l}\text { Aerobic-anaerobic } \\
\text { (oxygen source: } \\
\text { algae) }\end{array}$ & Facultative pond & $\begin{array}{l}\text { Deeper than oxidation ponds. } \\
\text { Photosynthesis and surface } \\
\text { reaeration provide oxygen for } \\
\text { aerobic stabilization in up- } \\
\text { per layers. Lower layers of } \\
\text { solids undergo anaerobic di- } \\
\text { gestion. }\end{array}$ & $\begin{array}{l}\text { Treatment of untreated, screened, } \\
\text { or primary settled wastewater and } \\
\text { industrial wastes. }\end{array}$ \\
\hline $\begin{array}{l}\text { Aerobic-anaerobic } \\
\text { (oxygen-source: } \\
\text { surface aerators } \\
\text { or submerged } \\
\text { tubing) }\end{array}$ & $\begin{array}{l}\text { Aerated or partial- } \\
\text { mix pond. }\end{array}$ & $\begin{array}{l}\text { As above, but mechanical sur- } \\
\text { face aerators or submerged } \\
\text { tubing used to provide oxygen. }\end{array}$ & $\begin{array}{l}\text { Treatment of untreated, screened, } \\
\text { or primary settled wastewater and } \\
\text { industrial wastes. }\end{array}$ \\
\hline
\end{tabular}

microbial activity at the bottom, accumulated sludge may not be degraded, resulting in a net sludge buildup. A typical design requirement in Alaska is to reserve about $5 \%$ of the lagoon volume for sludge deposits (EPA 1975).

In cases where the sludge accumulation rate equals the rate of decomposition or resuspension, the lagoon operates under steady-state conditions (Bartsch and Randal1 1971). Steady-state conditions may result after at least five years of operation for partial-mix aerated lagoons (Christianson and Coutts 1979, Christianson 1976), and may require from two to 20 years of operation before being established in facultative lagoons (Marais 1970, Stander et al. 1970). Lagoons located in cold climates, however, may never reach a steady-state condition. Clark et a1. (1970) reported that, for lagoons in Alaska, bottom sludge definitely accumulates faster than it is stabilized. This is true for both facultative and aerated lagoons.

Typically, lagoon operation involves a net sludge buildup during low temperature, winter months (Huray 1977), followed by temperature-dependent decomposition in the warmer summer months. Although temperature is a major consideration, other factors including lagoon inlet and outlet configuration, pond depth and geometry, and hydraulic and organic loading rates may also affect accumulation rates.

Sludge accumulation measurements in the Northway, Alaska, partial-mix aerated lagoon indicated an accumulation rate of over $2.54 \mathrm{~cm}$ ( 1 in.) per year, or about $0.25 \mathrm{~m}^{3}\left(9 \mathrm{ft}^{3}\right)$ per 1000 people per day, during 4.5 years (Clark et a1. 1970). A pilot aerated lagoon at Eielson AFB, Alaska, which received effluent from a primary plant, experienced an accumulation rate of 
$1.27 \mathrm{~cm}(0.5 \mathrm{in.})$ per year sludge in the third of the pond nearest the inlet of the pond, and $0.63 \mathrm{~cm}(0.25 \mathrm{in}$ ) to $1.27 \mathrm{~cm}(0.5 \mathrm{in.})$ per year in the final two-thirds of the pond (Reid 1970).

At several facultative lagoon sites in Canada and Alaska, sludge accumulation rates varied from 0.25 to $0.40 \mathrm{~m}^{3}$ (8.8 to $14.0 \mathrm{ft}^{3}$ ) per 1000 people per day, with the highest accumulation rates occurring at the more northerly sites; sludge accumulated at somewhat lower rates in aerated lagoons (Clark et a1. 1970). After five years of operation, the aerated lagoon at Fort Greely, Alaska, had $50.76 \mathrm{~cm}$ (20 in.) of accumulated sludge near the inlet, tapering down to $3.17 \mathrm{~cm}(1.25 \mathrm{in}$.) at about $15.2 \mathrm{~m}(50 \mathrm{ft})$ from the inlet. The secondary cell was about $50 \%$ covered with $3.17 \mathrm{~cm}(1.25 \mathrm{in}$.) to $5.08 \mathrm{~cm}$ (2 in.) of sludge (Christianson and Coutts 1979). This lagoon at Ft. Greely receives primary effluent from an existing Imhoff tank system.

A facultative lagoon in Columbia, Missouri, was sampled for accumulated sludge following three years of operation (Howard 1967). Sampling sites were randomly selected at various points in the lagoon, with sludge depths ranging from $5.1 \mathrm{~cm}$ (2 in.) to $10.2 \mathrm{~cm}$ (4 in.) outside the inlet deposition zone and from $8.9 \mathrm{~cm}(3.5 \mathrm{in.})$ to $15.2 \mathrm{~cm}$ (6 in.) inside the inlet deposition zone. These values convert to an annual accumulation rate of approximately $3 \mathrm{~cm}$ (1.2 in.). Other studies of sludge accumulation rates in arctic, subarctic, and temperate regions generally support these values (Boulier and Atchison 1975, U.S. Army 1975, Gloyna 1971, Parker and Skerry 1968, and Pick et a1. 1970).

At the lagoons in Winnipeg, Manitoba, the effect of discontinuing influent flow for four months was investigated. The aerated lagoons showed only slight evidence of bottom sludge reduction during this period (Girling et a1. 1974). In some locations a significant portion of the accumulated sludge is silt rather than organic solids (Middlebrooks et al. 1965). There may be from 23 to 91 times more silt than organics in some lagoon sludge deposits (Clare et al. 1960). However, the higher concentration of silts may be more likely to characterize lagoons operated in temperate regions because many cold regions lagoons have rubber membrane liners and are fed by sewer systems which exclude storm and other surface water.

\section{Lagoon Sludge Characteristics}

Lagoon sludge characteristics are as varied as lagoon sites; however, some general sludge characteristics have been defined. Table 2 presents the 
Table 2. Biological characteristics of lagoon sludges.

\begin{tabular}{|c|c|c|c|c|c|c|c|c|c|}
\hline $\begin{array}{l}\text { Sludge } \\
\text { type }\end{array}$ & $\begin{array}{l}\text { Facility } \\
\text { location }\end{array}$ & $\begin{array}{r}\text { Total } \\
\text { solids } \\
(\%)\end{array}$ & $\begin{array}{c}\text { Volatile } \\
\text { solids } \\
(\%)\end{array}$ & $\mathrm{pH}$ & $\begin{array}{l}\begin{array}{l}\text { Fecal } \\
\text { coliform } \\
\text { (MPN/g) }\end{array} \\
\end{array}$ & COD & Color & Odor & Reference \\
\hline $\begin{array}{l}\text { Aerated } \\
\text { lagoon }\end{array}$ & $\begin{array}{l}\text { Northway, } \\
\text { Alaska }\end{array}$ & $12-20$ & $29-50$ & $7.1-7.6$ & $\begin{array}{l}2.4\left(10^{3}\right) \\
4.9\left(10^{3}\right)\end{array}$ & $46-88 \mathrm{mg} / \mathrm{g}$ & Black & Musty & $\begin{array}{l}\text { Christianson and } \\
\text { Coutts (1979) } \\
\text { Clark et al. (1970) }\end{array}$ \\
\hline $\begin{array}{l}\text { Aerated } \\
\text { lagoon }\end{array}$ & $\begin{array}{l}\text { Winnipeg, } \\
\text { Manitoba }\end{array}$ & $8-10$ & $45-55$ & & & & & & Pick et al. (1970) \\
\hline $\begin{array}{l}\text { Aerated } \\
\text { lagoon }\end{array}$ & $\begin{array}{l}\text { Eielson } \\
\text { AFB } \\
\text { Alaska }\end{array}$ & $3 \cdot 6-9 \cdot 1$ & $55-93$ & & & & $\begin{array}{l}\text { Gray- } \\
\text { brownish } \\
\text { black }\end{array}$ & $\begin{array}{l}\text { Fresh } \\
\text { sewage }\end{array}$ & Reid (1970) \\
\hline $\begin{array}{l}\text { Facul- } \\
\text { tative } \\
\text { lagoon }\end{array}$ & $\begin{array}{l}\text { Co lumbia, } \\
\text { Míssouri }\end{array}$ & & & & & $800 \mathrm{mg} / \mathrm{in.}{ }^{2}$ & $\begin{array}{l}\text { Black- } \\
\text { gray }\end{array}$ & & Howard $(1967)$ \\
\hline $\begin{array}{l}\text { Anaerobic } \\
\text { lagoon }\end{array}$ & $\begin{array}{l}\text { Melbourne, } \\
\text { Australia }\end{array}$ & 14.9 & 38.3 & 7.5 & & & & & G1 oyna (1971) \\
\hline $\begin{array}{l}\text { Anaerobic } \\
\text { 1agoon }\end{array}$ & $\begin{array}{l}\text { Werribee, } \\
\text { Australia }\end{array}$ & $1.2-7.0$ & $41-60$ & & & & & & $\begin{array}{l}\text { Parker and } \\
\text { Skerry }(1968)\end{array}$ \\
\hline $\begin{array}{l}\text { Untreated } \\
\text { primary }\end{array}$ & & 2.8 & $60-80$ & $5.0-8.0$ & $1.1\left(10^{4}\right)$ & & & & $\begin{array}{l}\text { Metcalf and Eddy } \\
(1979) \text {, Farrell } \\
(1974)\end{array}$ \\
\hline
\end{tabular}

biological characteristics of lagoon sludges from several sources, and provides a comparison between these sludges and conventional primary sludge.

\section{Lagoon Sludge Removal Techniques}

Specific criteria for lagoon sludge removal are limited. Common practice for removing sludge from unlined or clay-lined lagoons usually involves draining the lagoon and excavating the sludge with a scraper or a front end loader.

Operators at Moose Jaw, Saskatchewan, removed accumulated sludge from their aerated lagoon by first removing the aeration tubing during warmer months. With the arrival of winter, the sludge froze and was subsequently removed by front end loaders (Lawson 1977).

Dredging operations first loosen the accumulated sludge for pumping to holding tanks (Water and Sewage Works 1970). Clogging of the pump suctions on a sludge dredging operation at Red Deer, Alberta, required the use of cutting heads on the suction pipes (Lawson 1977). These cutting heads would not be feasible with membrane-lined ponds. Sludge pumps are available to meet various requirements (EPA 1979).

To facilitate cleaning, designs should be based on a three-pond system employing two active cells and one inactive cell. After each cell is rested, the accumulated sludge can be removed by pumping or excavation (Dawson and Grainge 1969). 
Sludge stability may be judged by its tendency to harm the environment and produce nuisance conditions. When harmful environmental effects and nuisance potential are minimized, the sludge is stable and requires no further treatment (Vesilind 1974). In addition to in situ stabilization, sludge removed from lagoons can be further treated by aerobic digestion, anaerobic digestion, heat treatment, lime stabilization, pasteurization, chlorine oxidation, composting, chemical fixation, and long-term storage (EPA 1976). Lime stabilization and freeze-thaw conditioning are discussed below because of their enhanced potential use for stabilizing lagoon sludges in northern regions. The other methods listed above require a significant physical plant investment for their operation and would not, therefore, be cost effective for the infrequent treatment of lagoon sludge.

Lime Stabilization

Lime addition stabilizes sludge by raising the $\mathrm{pH}$ to high enough levels to destroy pathogens. Lime also reduces odors and improves dewaterability but produces large quantities of inorganic sludge (Vesilind 1974). At high levels of alkalinity, the bacterial kill rate will still be very high at 1 ow temperatures (Wang et a1. 1978), making this option attractive for cold regions application. Table 3 illustrates the effectiveness of lime in reducing pathogenic and indicator bacteria count. These data are from chemical-primary sludge produced at a conventional wastewater treatment pilot plant (Farrell et a1. 1974). Studies conducted at the Greenwood, South Carolina, treatment plant indicate that complete destruction of Salmonella typhosa results upon addition of lime in large enough quantities to produce a $\mathrm{pH}$ value of at least 12.0 (Doyle 1967).

Research at Lebanon, Ohio, also shows significant pathogen reduction with high $\mathrm{pH}$ values resulting from lime addition to wastewater sludges. The Salmonella typhosa and Pseudomonas aeruginosa concentrations are reduced to near zero. The total and fecal coliform reductions exceeded $99.99 \%$, and the fecal streptococci kills approached $99.93 \%$ for primary sludges (Noland and Edwards 1977). The effectiveness of lime stabilization in reducing total coliform bacteria at low temperatures is shown in Figure 1 (Morrison et al. 1973).

The $\mathrm{pH}$ value and contact time required to achieve the pathogen destruction discussed above varies. However, when sludge is treated in the liquid 
Table 3. Bacterial count reduction from lime addition to liquid municipal sludge (Farrell et al. 1974).

\begin{tabular}{|c|c|c|c|c|c|}
\hline Bacteria & $\begin{array}{c}\text { Original } \\
\text { count } \\
\text { (bacterial } \\
100 \mathrm{~mL}^{*} \text { ) }\end{array}$ & $\begin{array}{l}\mathrm{pH} 10.5 \\
0.5 \mathrm{hrt} \\
\end{array}$ & $\begin{array}{l}\mathrm{mH} 11.5 \\
0.5 \mathrm{hrt}\end{array}$ & $\begin{array}{ll}\mathrm{pH} & 11.5 \\
24 \mathrm{hrt}\end{array}$ & $\begin{array}{l}\mathrm{pH} 12.5 \\
0.5 \mathrm{hr} \dagger\end{array}$ \\
\hline Fecal coliform & $3.6 \times 10^{7}$ & 0.81 & 0.00028 & 0.00011 & 0.00011 \\
\hline Fecal streptococci & $2.2 \times 10^{6}$ & 10.0 & 0.17 & 0.059 & 0.009 \\
\hline Total aerobic count & $4.9 \times 10^{9}$ & 0.11 & 0.00067 & 0.00025 & 0.00071 \\
\hline Salmonella sp. & $>1,100$ & 0.0033 & $<0.0027$ & $<0.0027$ & $<0.0027$ \\
\hline Pseudomonas aeruginosa & 1,100 & 0.0083 & 0.0033 & 0.0027 & 0.0027 \\
\hline
\end{tabular}

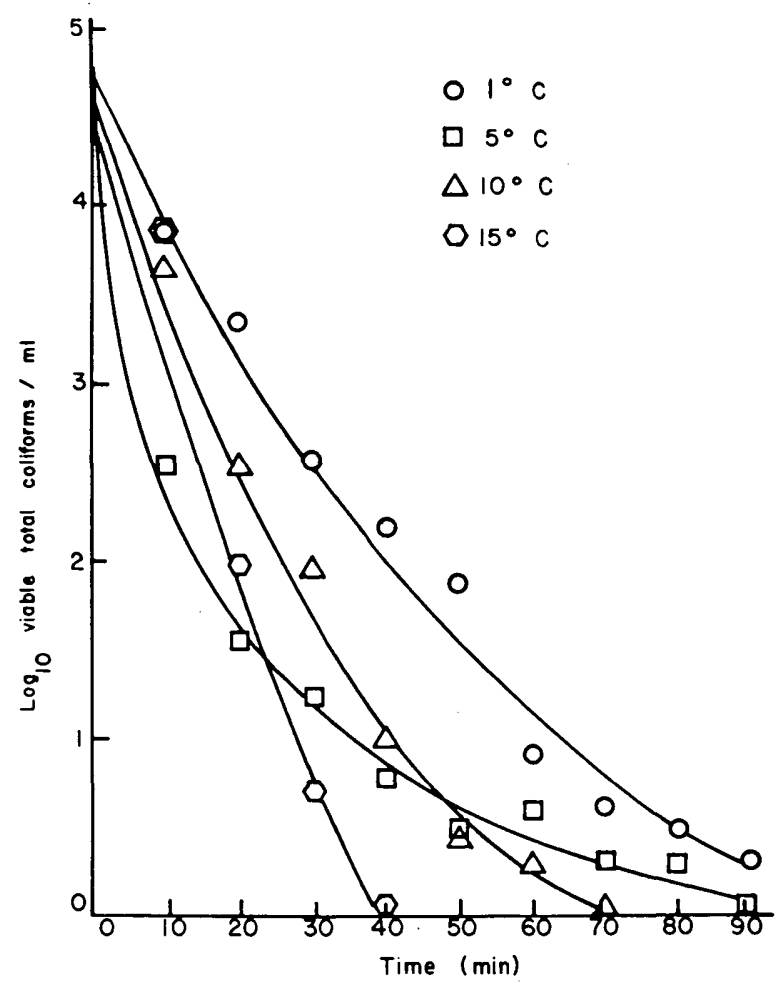

Figure 1. Total coliform bacteria reduction in lime treated wastewater at an initial $\mathrm{pH}$ of 12.0 , at $1^{\circ} \mathrm{C}$ to $15^{\circ} \mathrm{C}$ (Morrison et a1. 1973). 
state, and the lime added is sufficient to raise the $\mathrm{pH}$ to 12.5 for $30 \mathrm{~min}$, the following objectives are accomplished: 1) the $\mathrm{pH}$ remains above 12.0 for about $2 \mathrm{hr}$, resulting in the desired pathogen kill, and 2) the $\mathrm{pH}$ remains above 11.0 for several days, allowing use or disposal without renewed purification (EPA 1979). Several other sources also indicate the necessity of maintaining the $\mathrm{pH}$ above 12.0 for at least $30 \mathrm{~min}$ to achieve the desired stabilization (EPA 1978a, Metcalf and Eddy 1979, Morrison et al. 1973, Noland and Edwards 1977, Ramirez and Malina 1980, and Schroeder and Cohen 1977).

Figure 2 depicts the combined lime dosage vs $\mathrm{pH}$ for several sludges (EPA 1978a). Of the total amount of lime required for the sludges in Figure 2 to reach $\mathrm{pH} 12$, an additional 0 to $50 \%$ was added to maintain the $\mathrm{pH}$ value at 12 (EPA 1978a).

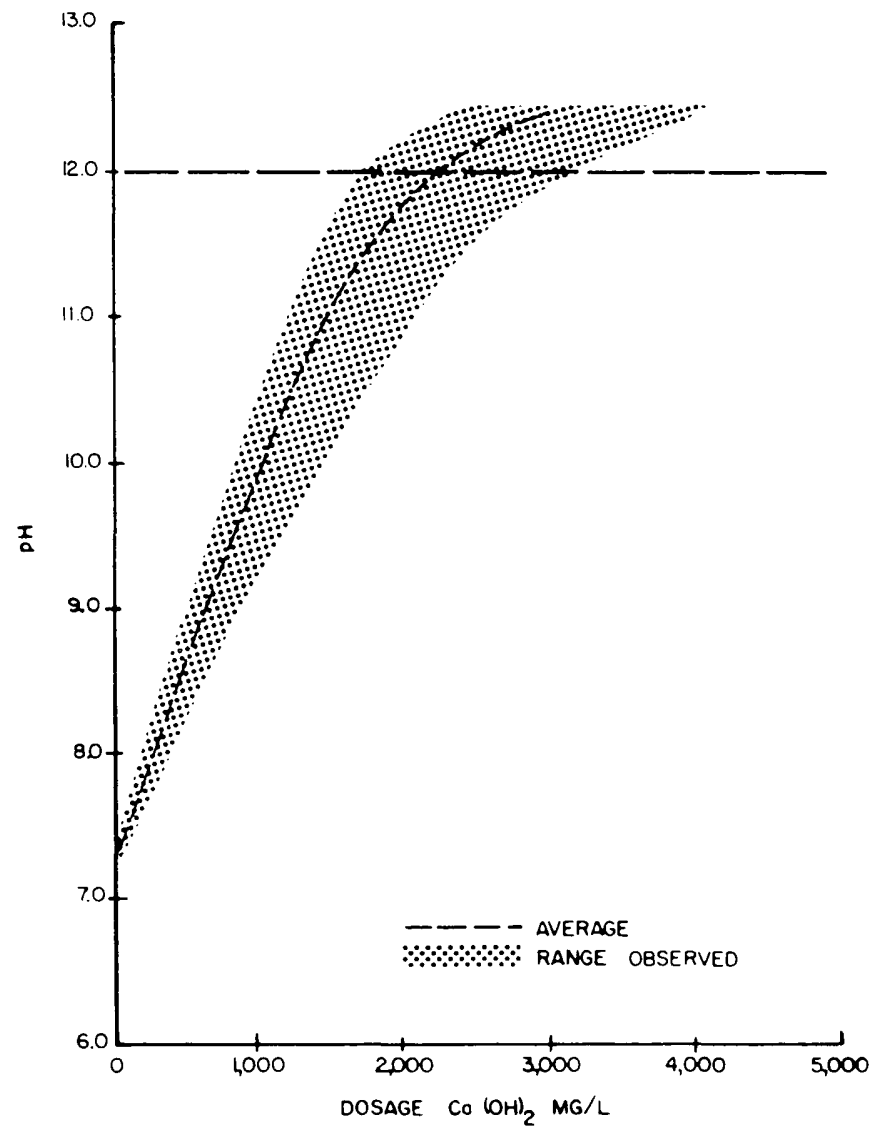

Figure 2. Combined lime dosage versus $\mathrm{pH}$ for primary, anaerobically digested, waste activated, and septage sludges (EPA 1978a). 
The lime dose necessary to keep the $\mathrm{pH}$ value above 11.0 for at least 14 days varied from 100 to $150 \mathrm{~g} \mathrm{Ca}(\mathrm{OH})_{2} / \mathrm{kg} \mathrm{SS}\left(0.22\right.$ to $-0.331 \mathrm{~b} \mathrm{Ca}(\mathrm{OH})_{2} 1 \mathrm{~b}$ SS) for primary sludge to 300 to $500 \mathrm{~g} \mathrm{Ca(OH})_{2} / \mathrm{kg}$ SS $(0.66 \text { to }-1.101 \mathrm{~b} \mathrm{Ca(OH})_{2} / 1 \mathrm{~b}$ SS) for biological sludge. No differences in dosage requirements were evident between lime added as a slurry and lime added dry (Paulsrud and Eikum 1975).

\section{Freeze-thaw Conditioning}

Freeze-thaw conditioning is a sludge treatment process where liquid sludge is placed on sand drying beds and allowed to freeze. The process is particularly attractive in cold regions where natural refrigeration can be used. The purpose of the freeze-thaw technique is to condition the sludge so that it is readily dewaterable and to reduce the volume of sludge to be disposed of. Variables in the process are the depth of sludge to be frozen and the rate at which the sludge freezes. Although freeze-thaw conditioning does not produce the pathogen destruction of lime stabilization (Leclerc and Brouzes 1973, Tilsworth 1972), it does produce an odorless and easily handled humus-like product (Tilsworth 1972).

A Canadian study concluded that "improved dewaterability can be expected for any sludge type if complete freezing is attained at a relatively slow rate such as that found in the natural environment" (Rush and Stickney 1979). However, the filtrate quality from these sludges was from three to six times poorer than that from $r$ aw wastewater. The filtrate return to the treatment system resulted in $0.8 \%$ increase in hydraulic loading and $5.0 \%$ increase in organic loading.

Freezing rate is important because the dehydrating and pressure producing properties of the ice structure are affected (Katz and Mason 1970). The freezing process breaks down molecular bonds and releases water molecules contained in the sludge. Sludge dewaters when frozen at rates up to 40 to 60 $\mathrm{mm} / \mathrm{hr}$ ( 1.57 to $2.36 \mathrm{in.} / \mathrm{hr}$ ); however, the best sludge dewaterability occurs when the sludge was frozen at $20.5 \mathrm{~mm} / \mathrm{hr}(0.81 \mathrm{in.} / \mathrm{hr}$ ) (Logsdon and Edgerly 1971). Sludges dewater more readily when frozen at higher rates if treated with polymers to reduce specific resistance. Additional studies indicate that sludges can be frozen at relatively high rates when in thin films at small temperature differences. This process requires chemical additives (Cheng et al. 1970). Experience at a facility in Monroe County, New York, indicated a total solids increase from $3.5 \%$ to $17.5 \%$ with a decrease in over- 
a11 volume for sludges subjected to freeze-thaw action (Bishop and Fulton 1968).

Research conducted at the University of Alaska concludes that slow freezing produces a better conditioned sludge than does fast freezing (Tilsworth 1972). Also, improved efficiency occurs with more dilute sludge composed of 1 to $2 \%$ solids. The Alaskan researchers indicated that, where natural refrigeration is employed, the sludge depth depends upon the local climatology. Greater depths result in smaller area requirements, but artificial heating methods may be required for thawing during the spring. This process is especially suited for cold regions where small facilities with 1 ow sludge volume can take advantage of abundant land and natural refrigeration.

Lagoon Sludge Disposal

The ultimate disposal of wastewater sludge can take many forms including burning, burying, or spreading on land (Heckroth 1971). Of these various methods, sludge disposal on land usually provides the most cost-effective solution to sludge management problems. Lime treatment prior to land application should stabilize the sludge with respect to pathogens and odors and result in a material that is safe and aesthetically acceptable.

Application of sewage sludge to agricultural land as a soil conditioner and fertilizer, and application to damaged soils as a conditioner has been a common practice (Evans 1969, Farrel1 1974, and Vesilind 1974). This is because land application is usually less expensive and less energy intensive than most other methods of disposal. An added benefit is that nutrients and organic matter are put back in the soil and the condition of the soil is improved.

Summary

The literature indicates that substantial work has been conducted in the areas of lime stabilization and land disposal of primary, secondary, and waste-activated sludges. However, factors affecting sludge accumulation, methods of removal for accumulated sludge, stabilization of accumulated sludge, and specific sludge characteristics have been generally neglected relative to cold regions wastewater lagoons.

The literature does indicate that sludge will accumulate to varying degrees in wastewater lagoons. This accumulation poses a threat to wastewater treatment efficiency by reducing the pond volume available for treatment. The characteristics of the accumulated sludges can influence decomposition 
rates and may significantly influence the handling and ultimate disposal of sludge removed from wastewater lagoons.

\section{MATERIALS AND METHODS}

Introduction

Sludge accumulation was determined at two Utah facultative lagoon systems and two Alaskan aerated lagoons. Samples were collected and stored at temperatures reflecting winter conditions at the bottom of the lagoon to evaluate the sludge stabilization processes occurring in cold regions lagoons. In addition, bench-scale aerobic and anaerobic digestion studies were performed. Lime stabilization was also investigated as a treatment process for sludges and the stability of these lime-treated sludges on open soil and sand beds was monitored.

Sampling Procedure

Table 4 presents characteristics and background data for the four lagoon sites studied during this project. The sludge layers in the primary cell of each lagoon system were measured for thickness to determine sludge accumulation rates and sludge distribution and volume. To determine suitable sampling points, as well as to map the accumulated sludge depth, a grid pattern was established by marking the lagoon berm at regular intervals. Samples were collected from a boat that was positioned at the appropriate points between opposite berm markings. Figures $3,4,5$, and 6 show the sampling point locations and dimensions of the grids.

Table 4. Description of lagoon sites.

\begin{tabular}{|c|c|c|c|c|}
\hline & Logan, Utah & Corinne, Utah & Palmer, Al aska & Galena, Alaska \\
\hline $\begin{array}{l}\text { Average annual } \\
\text { temperature range }\end{array}$ & $15^{\circ} \mathrm{F}$ to $85^{\circ} \mathrm{F}$ & $20^{\circ} \mathrm{F}$ to $90^{\circ} \mathrm{F}$ & $5^{\circ} \mathrm{F}$ to $65^{\circ} \mathrm{F}$ & $-20^{\circ} \mathrm{F}$ to $70^{\circ} \mathrm{F}$ \\
\hline System type & 7-cell facultative & 7-cell facultative & $\begin{array}{l}\text { Single cell, submerged } \\
\text { tubing aeration with } \\
\text { polishing pond }\end{array}$ & $\begin{array}{l}\text { Single cell, submerged } \\
\text { tubing aeration }\end{array}$ \\
\hline Year built & 1967 & 1973 & 1972 & 1975 \\
\hline Influent BOD $_{5}$ & $75 \mathrm{mg} / \mathrm{L}$ & $75 \mathrm{mg} / \mathrm{L}$ & $200 \mathrm{mg} / \mathrm{L}$ & $200 \mathrm{mg} / \mathrm{L}$ \\
\hline Influent TSS & $62 \mathrm{mg} / \mathrm{L}$ & $69 \mathrm{mg} / \mathrm{L}$ & $185 \mathrm{mg} / \mathrm{L}$ & $170 \mathrm{mg} / \mathrm{L}$ \\
\hline Influent VSS & $40 \mathrm{mg} / \mathrm{L}$ & $48 \mathrm{mg} / \mathrm{L}$ & - & -- \\
\hline
\end{tabular}




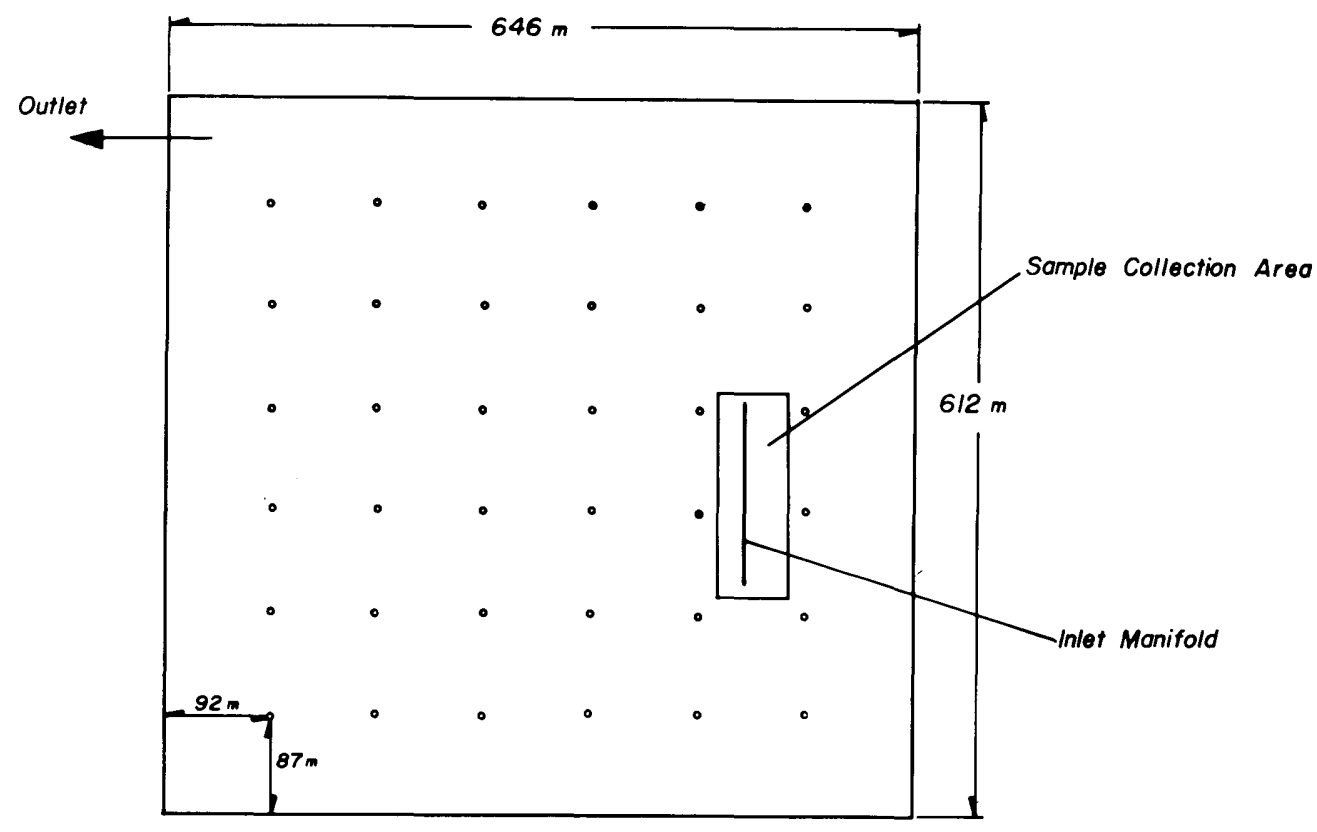

Figure 3. Sample collection area and grid dimensions for the Logan, Utah, wastewater lagoon system.

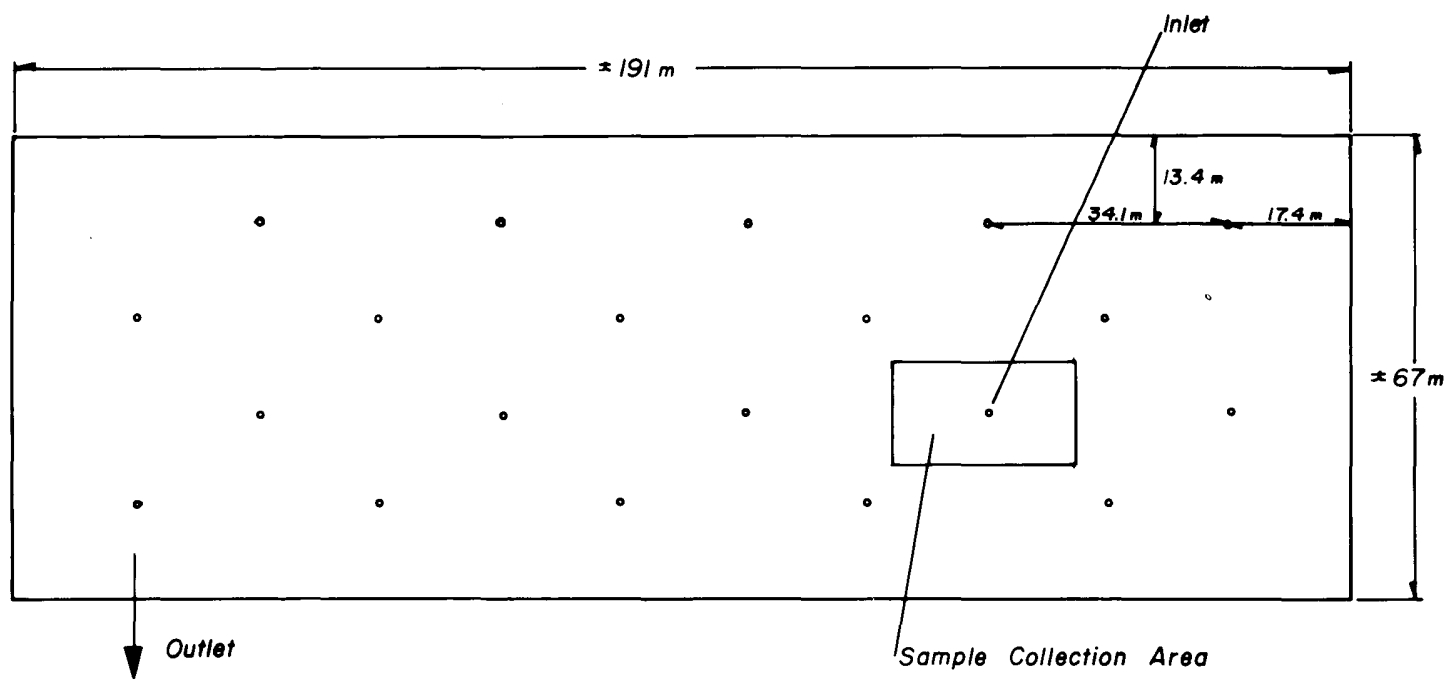

Figure 4. Sample collection area and grid dimensions for the Corinne, Utah, wastewater lagoon system. 


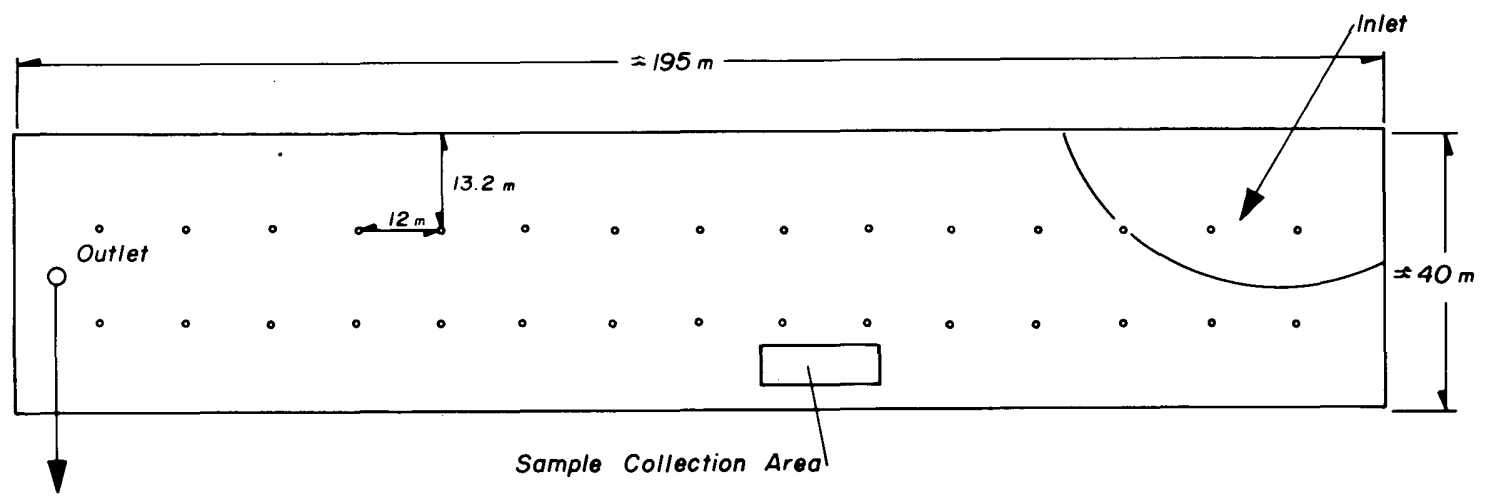

Figure 5. Sample collection area and grid dimensions for the Palmer, Alaska, wastewater lagoon system.

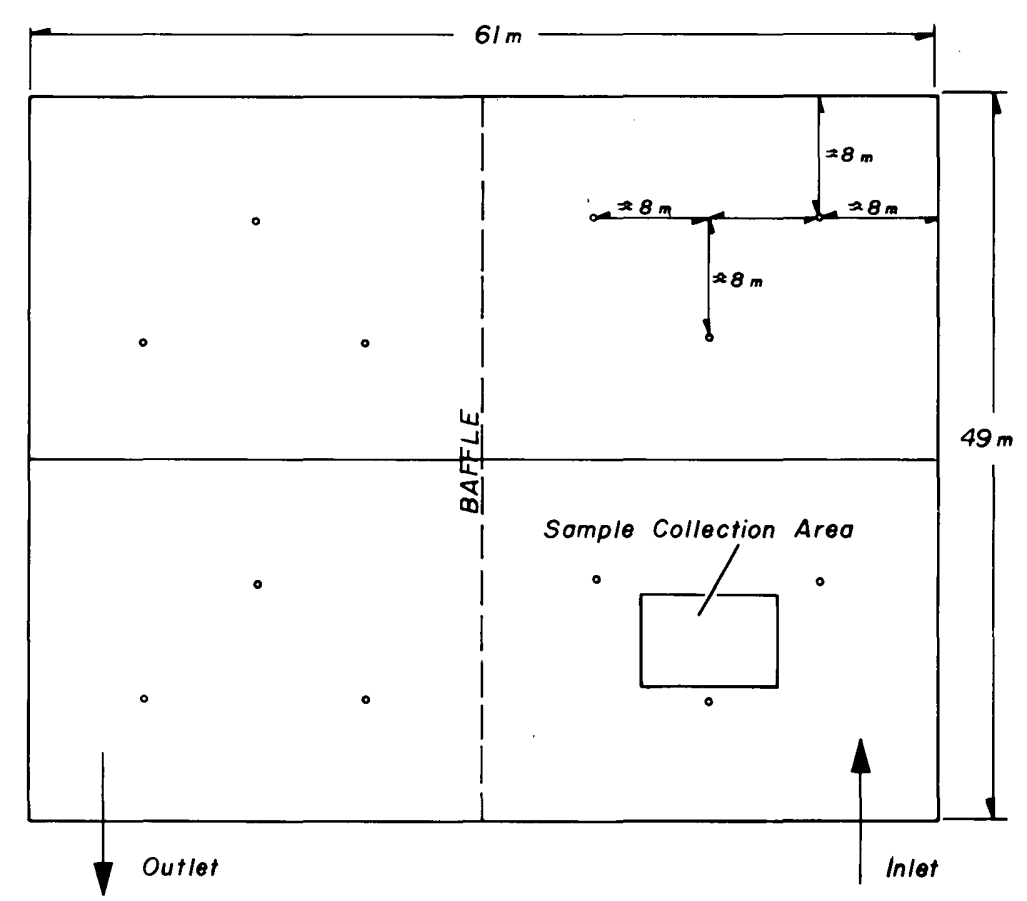

Figure 6. Sample collection area and grid dimensions for the Galena, Alaska, wastewater lagoon system.

The Logan and Corinne (Utah) sludges were collected in mid-March, 1980, just following the winter ice melt. The Palmer and Galena (Alaska) sludges were sampled early in June 1980. The Alaska lagoons had been free of ice for approximately two months prior to sampling.

As much uniformity as possible was exercised in collecting, handling, and storing the samples. The Alaskan sludge samples were shipped by air freight with refrigeration provided at stopover points; the Utah samples were placed in cold storage on the same day as collected. 
Sludge core samples were taken with a $1.2-m(4-f t)$ section of $5-\mathrm{cm}(2-i n$.$) out-$ side diameter $\times 3.8-\mathrm{cm}(1.5-\mathrm{in}$.$) inside di-$ ameter clear acrylic tubing. One end of the sampling tube was tapered to provide a cutting edge when pushed through the sludge into the pond bottom. The other end of the sampler was attached to $1.2-m(4-f t)$ sections of $2.54-\mathrm{cm}(1-\mathrm{in}$.$) PVC pipe, with$ sections added or removed to accommodate depth variance. A rubber stopper inserted in the end of the last section created a vacuum in the tube, preventing sample loss as the sampler was withdrawn from the lagoon. The sludge depth and sludge/silt interface were observed through the tube walls and sludge was measured using lines scribed on the tube at 2.54-cm (1-in.) intervals. Figure 7 illustrates the sludge core sampling tube. At Palmer and Galena, the grid system was established to provide sludge depth sampling points and a photoelectric cell was used to obtain sludge depth measurements.

The sludge depth device consists of a flashlight facing a photoelectric cell with the relative light intensity measured on a voltmeter. As the sludge/water interface

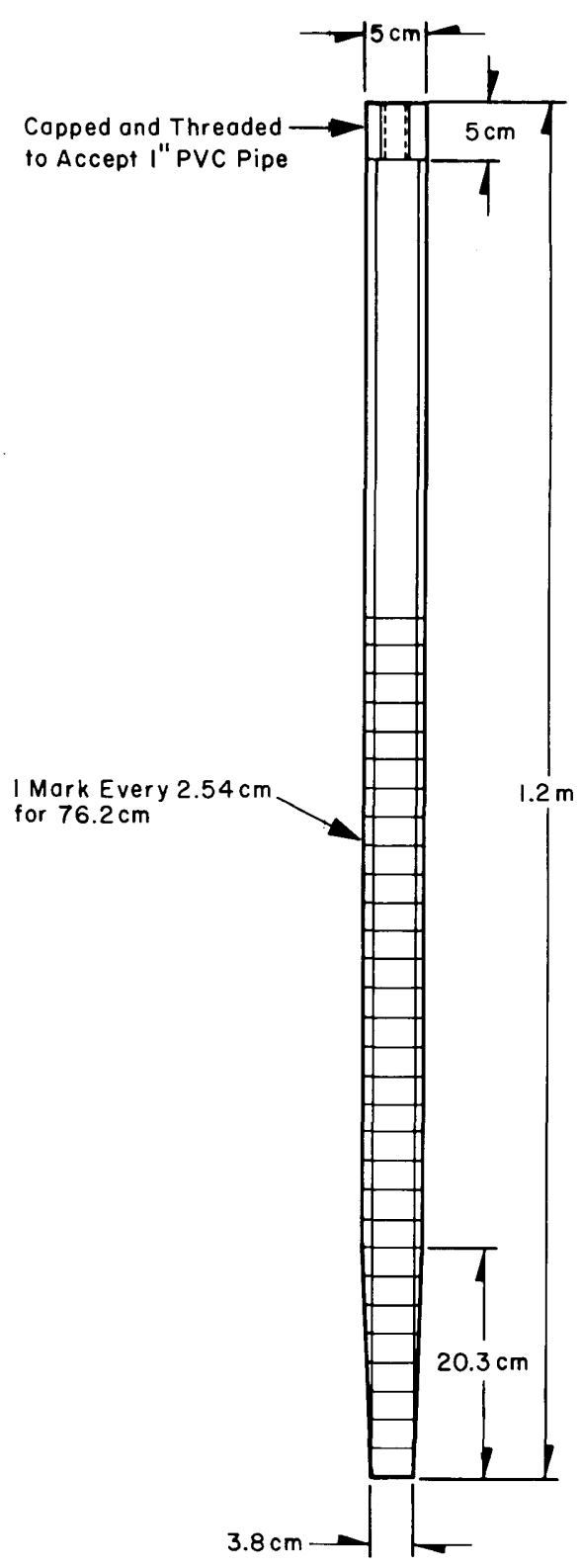

Figure 7. Lagoon sludge core sampling tube. is encountered, the light beam is interrupted and the meter deflects. The cell is then pushed through the sludge layer until stopped by the lagoon bottom. The total depth minus the depth to the sludge/water interface equals the sludge depth (Fig. 8).

Suitable sampling points required sufficient sludge depth $(15$ to $20 \mathrm{~cm})$ to allow pumping without excessive supernatant uptake. At each lagoon, between 1300 and $1400 \mathrm{~L}$ of sludge was collected and transported to Logan, Utah, for cold storage. 


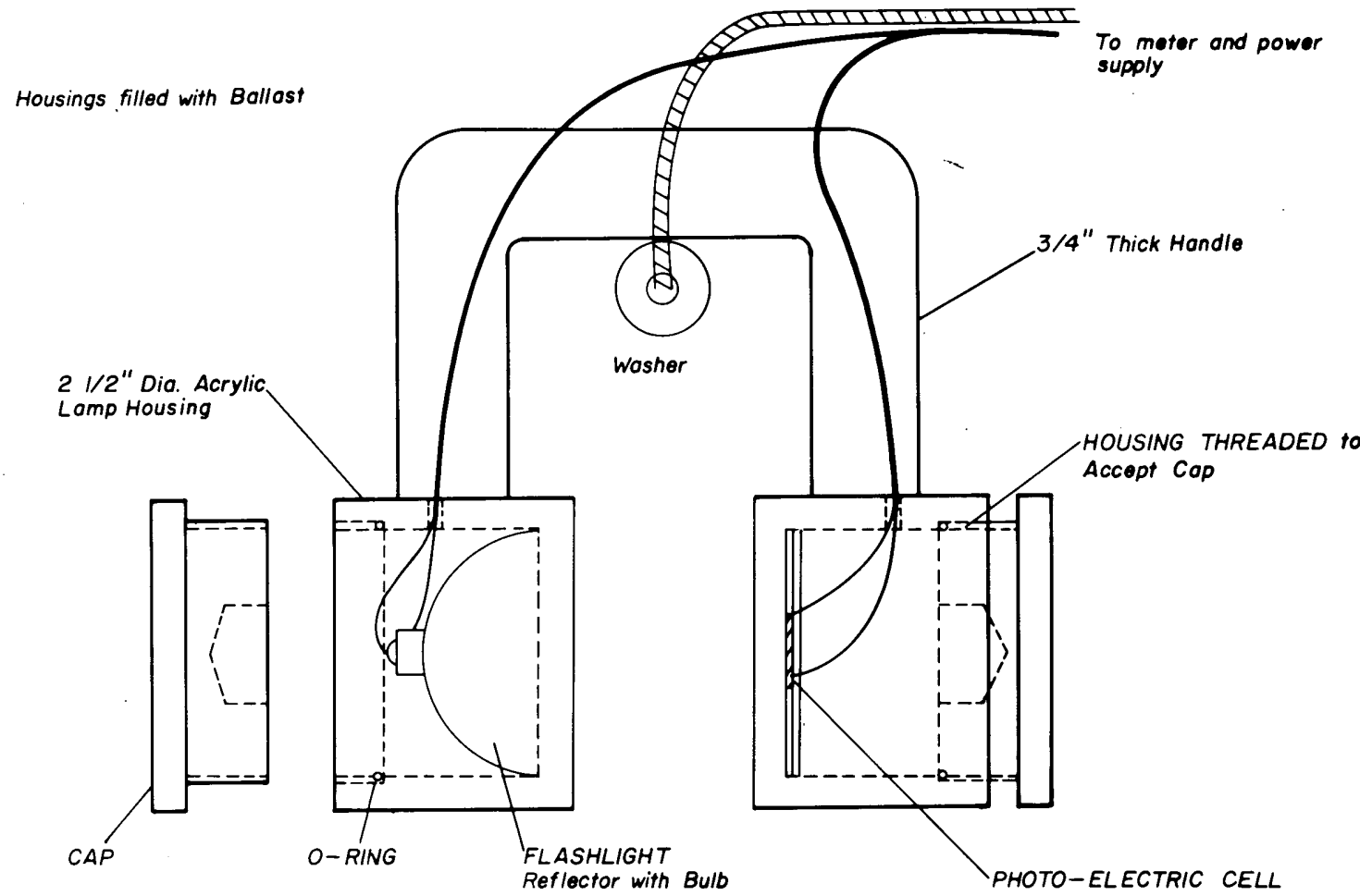

Figure 8. Schematic of the photo-electric cell used to determine accumulated sludge depth in the Palmer and Galena, Alaska, lagoons.

Within one week following collection, all of the sludge samples from a particular lagoon were mixed together in a $2-\mathrm{m}^{3}(500-\mathrm{gal})$ tank. The mixed sludge was then divided into separate 20 - L containers and returned to $4^{\circ} \mathrm{C}$ $\left(39.2^{\circ} \mathrm{F}\right)$ storage for stability studies and digestion experiments. The digestion experiments will be reported elsewhere.

\section{Lime Stabilization}

The 20-L (5-gal.) polyurethane containers used for sludge sample storage were also used for mixing of the lime addition. The lime-sludge mixture was stirred with mechanical mixers at approximately $120 \mathrm{rpm}$. The stirrers were mounted to laboratory ring stands and set at an angle and depth to provide complete mixing. A photograph of the lime stabilization apparatus is shown in Figure 9.

Smaller samples (2-L) of sludge were also lime stabilized to confirm lime dose requirements. These samples were mixed in $3-\mathrm{L}$ plastic bottles at approximately $80 \mathrm{rpm}$ using the same stirrers used with the 20-L (5-gal.) samples. 


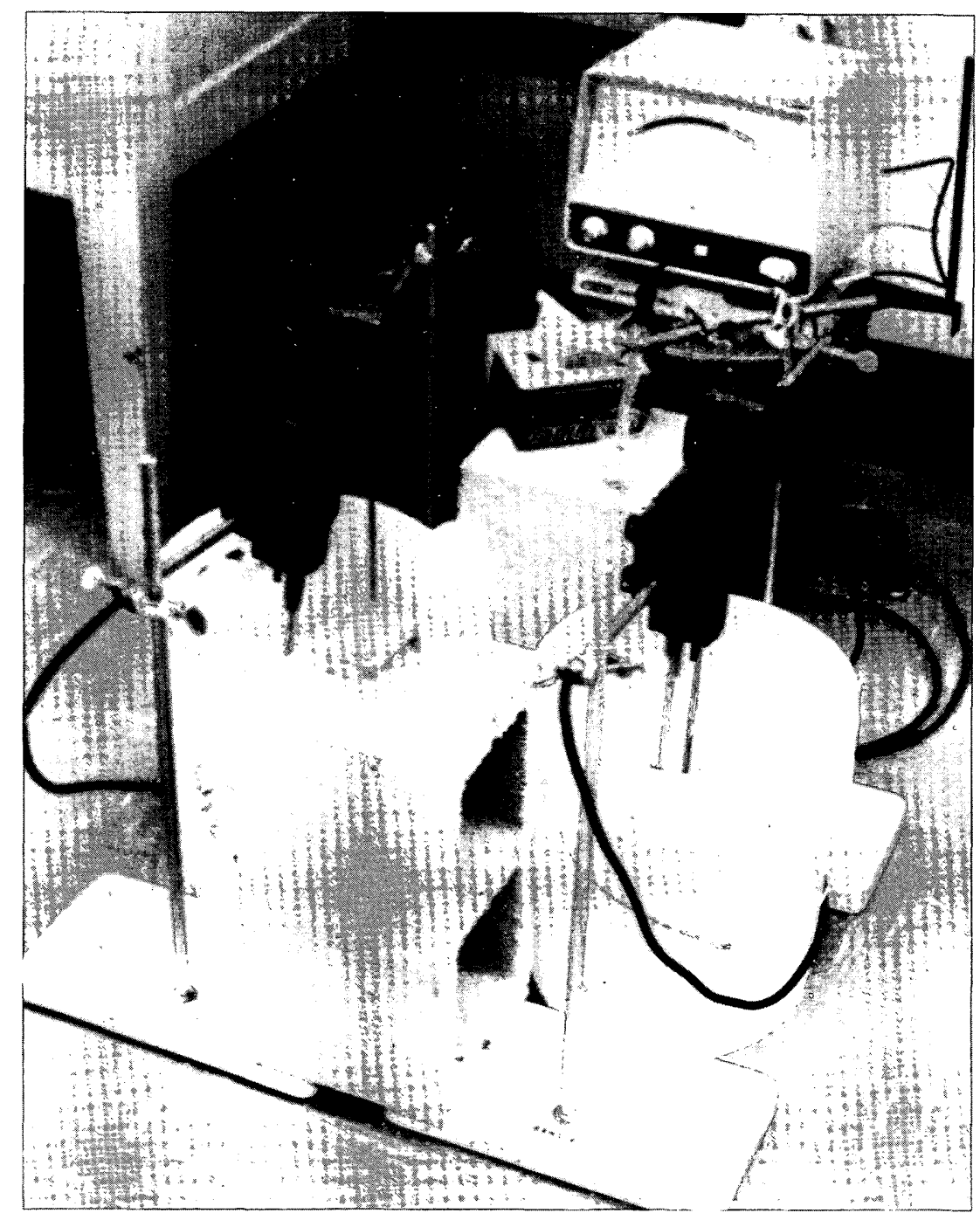

Figure 9. Lime stabilization apparatus.

\section{Sludge Drying}

Mode1 drying beds (1ysimeters) used for lime-treated sludge application were made from empty 20-L (5-ga1.) sample containers. The top halves of two containers were cut off and stacked inside a third, unaltered container to form a column $29.2 \mathrm{~cm}(11.5 \mathrm{in.})$ in diameter and $61 \mathrm{~cm}$ (24 in.) high. Several 8-mm (5/16-in.) holes were drilled in the bottom container to provide drainage. Sand particles passing a number 10 sieve and retained on a number 20 sieve were glued to the inner surface of each column to reduce hydraulic short-circuiting. Four columns were suspended in a square pattern between four concrete blocks. A total of eight lysimeters were used, one with sand and one with soil for each sludge. A catch pan was placed beneath each column to collect the leachate as it filtered through the media. Figure 10 


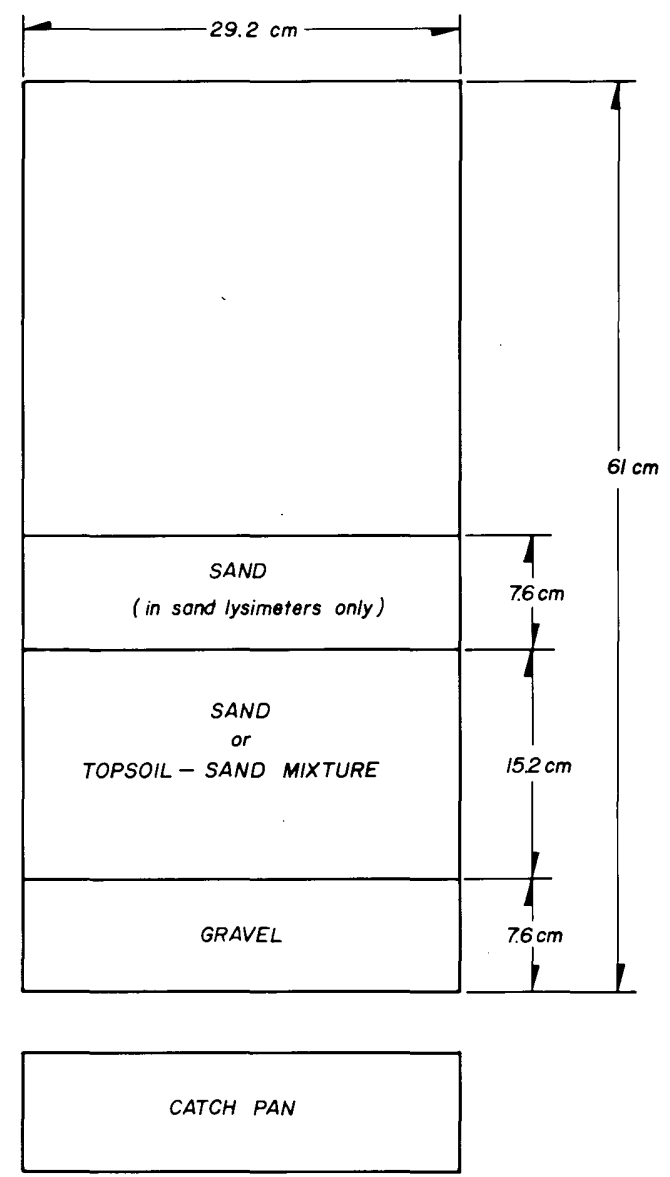

Figure 10. Schematic diagram of a lysimeter column.

shows a schematic drawing of a single column and Figure 11 shows the group of lysimeters.

\section{Experimental Procedures}

To characterize the lagoon sludges, samples were analyzed for total organic carbon (TOC), total solids (TS), volatile solids (VS), pH, total Kjeldahl nitrogen (TKN), ammonia nitrogen $\left(\mathrm{NH}_{3}-\mathrm{N}\right)$, and fecal coliforms shortly after collection. Also, selected metal concentrations were determined for each lagoon sludge. The sludge samples were stored at $4^{\circ} \mathrm{C}\left(39.2^{\circ} \mathrm{F}\right)$, and analyses for $\mathrm{TO}, \mathrm{TS}, \mathrm{VS}, \mathrm{pH}, \mathrm{TKN}, \mathrm{NH}_{3}-\mathrm{N}$, and fecal coliform were conducted weekly thereafter. These weekly analyses were used to determine sludge characteristic changes with time at low temperatures to serve as an indication of the stabilization occurring in the actual lagoon.

Hydrated lime $\left[\mathrm{Ca}(\mathrm{OH})_{2}\right]$ was added to $\mathrm{raw}$ lagoon sludge samples at $12^{\circ} \mathrm{C}$ until the $\mathrm{pH}$ value remained at 12.5 for $30 \mathrm{~min}$. The lime dose applied to 


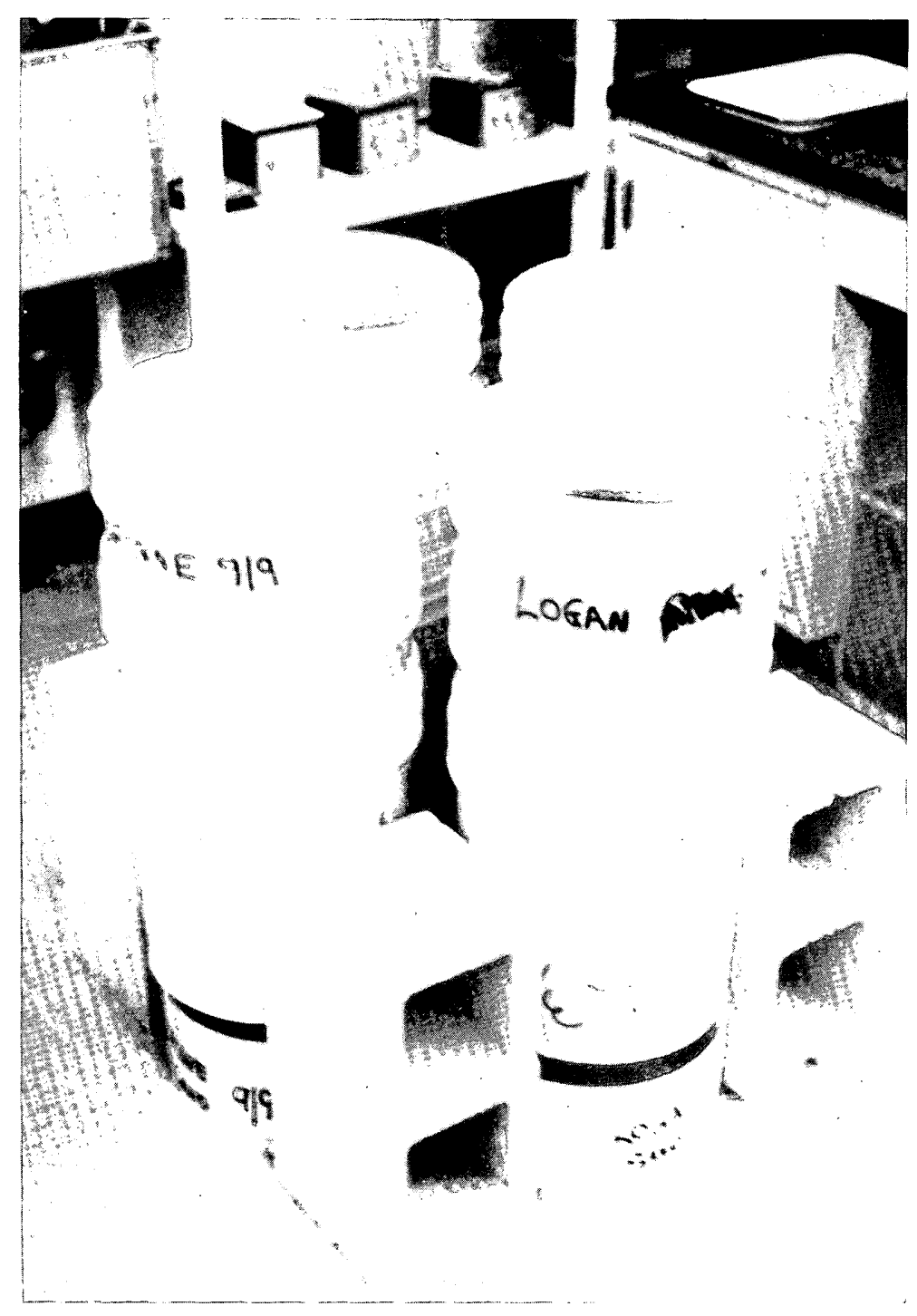

Figure 11. Sand lysimeter group.

each sludge was a function of the particular sludge characteristics. The lime was added dry, and mixed with the sludge by mechanical stirrers. Before the lime addition, the pH value of the raw sludge, fecal coliform count, and moisture content were determined. Monitoring of the $\mathrm{pH}$ value continued throughout the lime stabilization process. At the end of the 30-min contact period, stabilized sludge samples were taken for fecal coliform and moisture content analyses.

The sand and soil bed drying phase of the experiments consisted of taking the lime-stabilized sludges discussed above and spreading them over the surface of sand and soil drying beds at $12^{\circ} \mathrm{C}$. After 5, 10, 15, and 20 days, 
the sludges remaining on the surface of the beds were analyzed for moisture content, and the leachate was analyzed for $\mathrm{pH}$ and fecal coliform.

Sludge application rates applied to the soil were based on the nitrogen utilization capacity for sparsely forested land. Application rates for the sand were equivalent to rates normally applied to sludge drying beds in cold climates.

\section{RESULTS AND DISCUSSION}

\section{Introduction}

The sludge from several cold climate wastewater lagoons was examined in this study to determine accumulation rate, accumulated sludge characteristics, and to estimate the degree of stabilization that may be occurring. Also, a brief investigation of lime stabilization and land drying of the lagoon sludge was conducted.

\section{Accumulation}

Table 5 contains a summary of the sludge accumulation data collected from the Logan and Corinne, Utah, and the Palmer and Galena, Alaska, wastewater lagoons. The mean sludge depths and the influent suspended solid concentrations in the Logan and Corinne, Utah, lagoons are approximately three

Table 5. Lagoon sludge accumulation data summary.

\begin{tabular}{|c|c|c|c|c|}
\hline \multirow[b]{2}{*}{ Parameter } & \multicolumn{4}{|c|}{ Lagoon } \\
\hline & Logan & Corinne & Palmer & Galena \\
\hline F1ow, $\mathrm{m}^{3} /$ day & 37,850 & 694 & 681 & 284 \\
\hline $\begin{array}{l}\text { Surface area, } \mathrm{m}^{2} \\
\text { Bottom area, } \mathrm{m}^{2} \\
\text { Continuous operation since } \\
\text { lagoon was cleaned, yr }\end{array}$ & $\begin{array}{l}384,188 \\
345,000 \\
13\end{array}$ & $\begin{array}{l}14,940 \\
11,200 \\
9\end{array}$ & $\begin{array}{c}13,117 \\
8,100 \\
5\end{array}$ & $\begin{array}{l}2,520 \\
1,500 \\
8\end{array}$ \\
\hline $\begin{array}{l}\text { Mean sludge depth, cm } \\
\text { Total sludge solids } \\
\text { conc, g/L }\end{array}$ & $\begin{array}{r}8.9 \\
58.6\end{array}$ & $\begin{array}{r}7.6 \\
76.6\end{array}$ & $\begin{array}{l}33.5 \\
85.8\end{array}$ & $\begin{array}{r}27.7 \\
9.8\end{array}$ \\
\hline $\begin{array}{l}\text { Sludge volatile solids } \\
\text { conc, g/L }\end{array}$ & 40.5 & 61.5 & 59.5 & 4.8 \\
\hline $\begin{array}{l}\text { Influent total } \\
\text { suspended solids, mg/L }\end{array}$ & 62 & 69 & 185 & 170 \\
\hline $\begin{array}{l}\text { Influent volatile } \\
\text { suspended solids, mg/L }\end{array}$ & 40 & 48 & -- & -- \\
\hline
\end{tabular}


to four times lower than those in the Palmer and Galena, Alaska, lagoons. Although these sludges were accumulated over varying periods of time, the Utah facultative lagoons each have a mean sludge depth near $8 \mathrm{~cm}$ (3.1 in.) and the Alaskan aerated lagoons each have a mean sludge depth near $30 \mathrm{~cm}$ (11.8 in.). The distribution of the accumulated sludges over the lagoon bottoms is illustrated in Figures 12-15. An examination of the figures shows that the greatest solids deposition occurred near the inlet, as expected. Also, the figures indicate a greater tendency for incoming wastewater to short circuit through the square configuration lagoons.

Figure 16 shows the Palmer, Alaska, lagoon when drained and illustrates the sludge accumulation that occurred near the inlet of wastewater lagoons.

The influent total suspended solids (TSS) concentrations of roughly 200 $\mathrm{mg} / \mathrm{L}$ for the Palmer and Galena lagoons are considerably higher than the Logan and Corinne influent TSS concentrations of approximately $65 \mathrm{mg} / \mathrm{L}$. Thus, when comparing the Alaska lagoons to the Utah lagoons, a deeper sludge layer should be expected for the aerated lagoons in Alaska.

The Alaska lagoons experience lower temperatures for longer periods than do the Utah lagoons. During the five-month period from December through

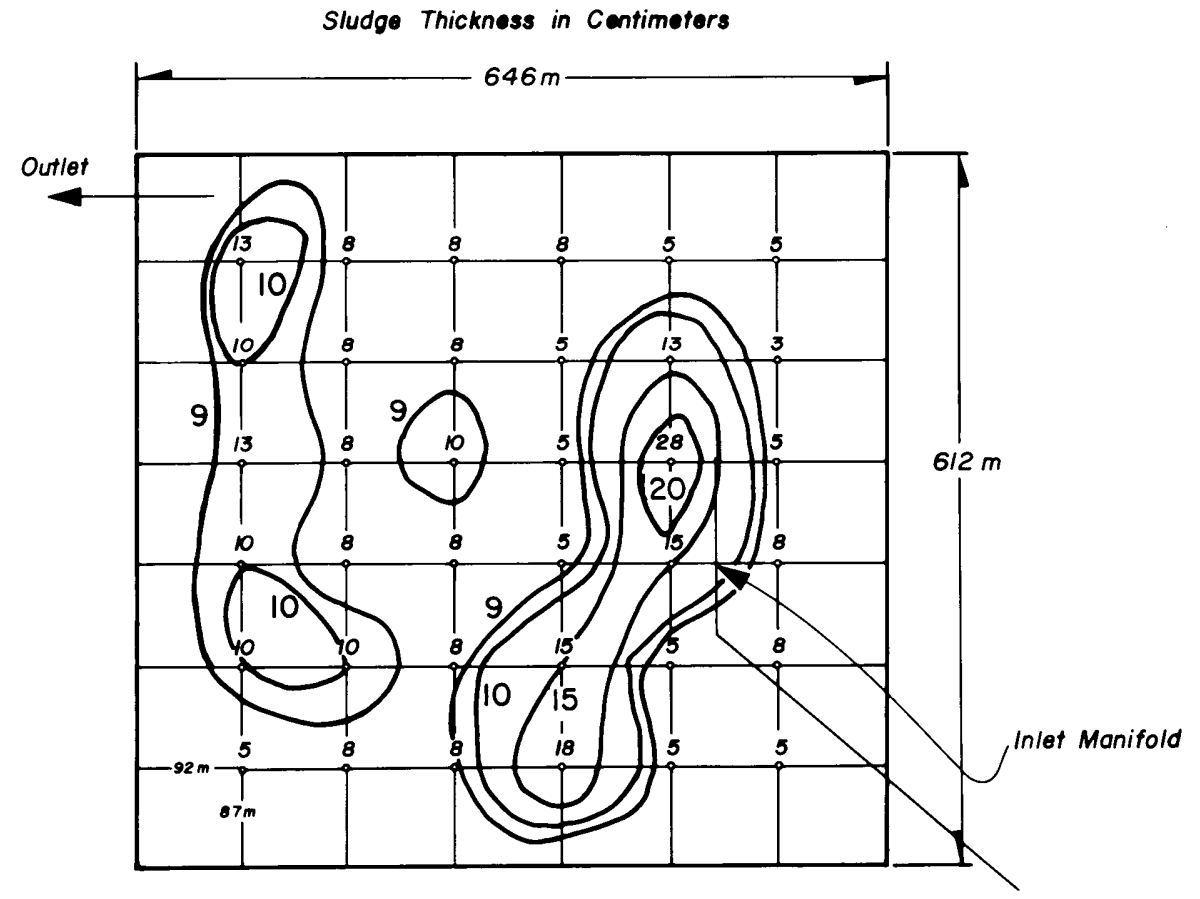

Figure 12. Sludge depth distribution over the bottom of the Logan, Utah, lagoon system cell A2. Contours indicate approximate isochronal lines for equal sludge accumulation $(\mathrm{cm})$. 


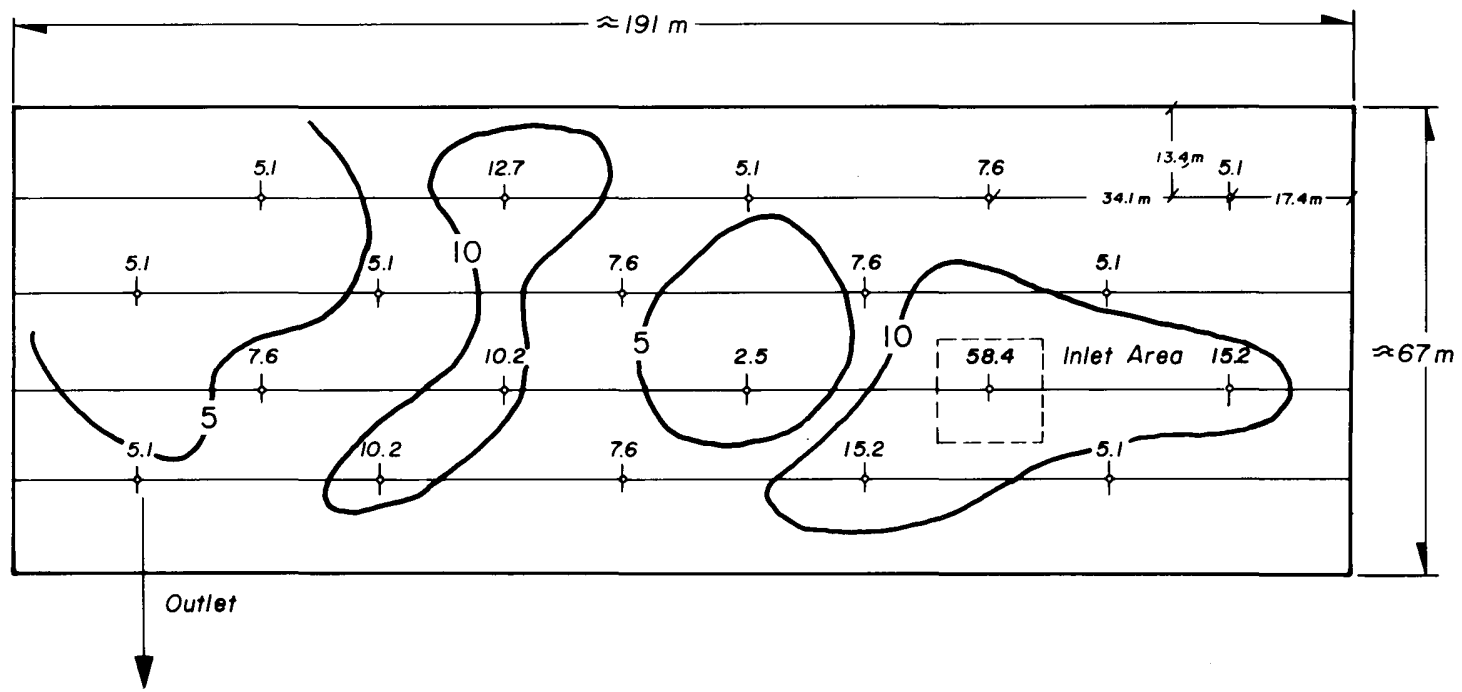

Figure 13. Sludge depth distribution over the bottom of the Corinne, Utah, lagoon system primary cell. Contours indicate approximate isochronal lines for each sludge accumulation $(\mathrm{cm})$.

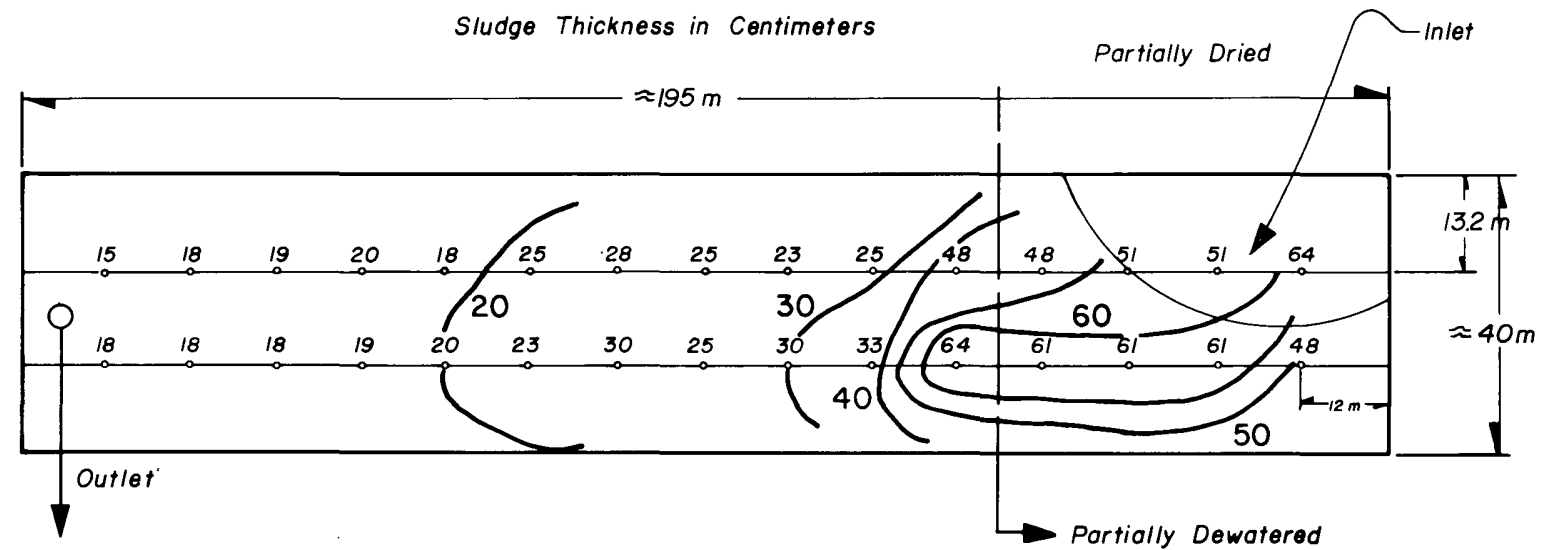

Figure 14. Sludge depth distribution over the bottom of the Palmer, Alaska, lagoon system aerated cell.

April, the Palmer influent is near $7^{\circ} \mathrm{C}\left(44.6^{\circ} \mathrm{F}\right)$ and the aerated cell effluent is near $0.5^{\circ} \mathrm{C}\left(32.9^{\circ} \mathrm{F}\right)$. For the Logan primary cell, the influent temperature is approximately $11^{\circ} \mathrm{C}\left(51.8^{\circ} \mathrm{F}\right)$ and the effluent temperature is approximately $3^{\circ} \mathrm{C}\left(37.4^{\circ} \mathrm{F}\right)$ for the three-month period from December through February. The Logan primary cell influent and effluent temperatures are roughly $16^{\circ} \mathrm{C}$ $\left(53.6^{\circ} \mathrm{F}\right)$ and $20^{\circ} \mathrm{C}\left(68^{\circ} \mathrm{F}\right)$ or higher for the three-month period of June, July, and August. The influent temperature to the Palmer lagoon exceeds $12^{\circ} \mathrm{C}$ $\left(53.6^{\circ} \mathrm{F}\right)$ for only August and September, while the effluent from the aerated 
Sludge Thickness in Contimoters

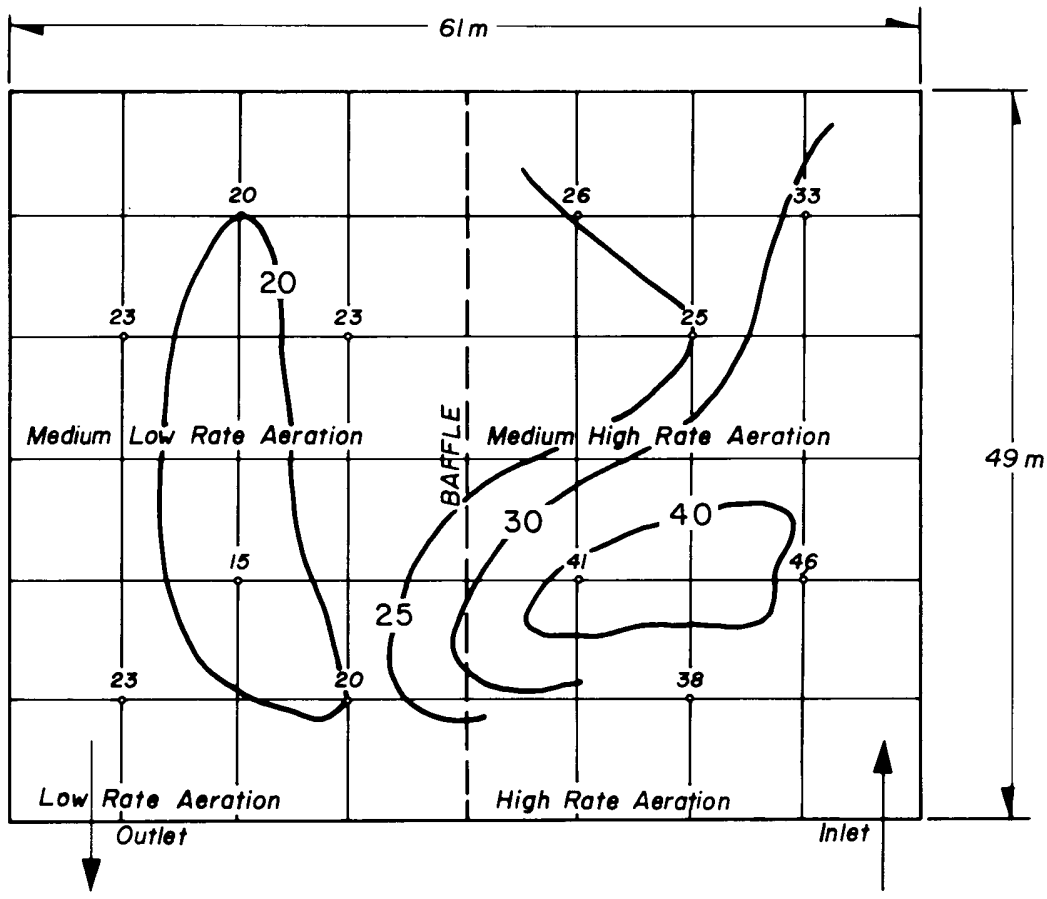

Figure 15. Sludge depth distribution over the bottom of the Galena, Alaska, lagoon.

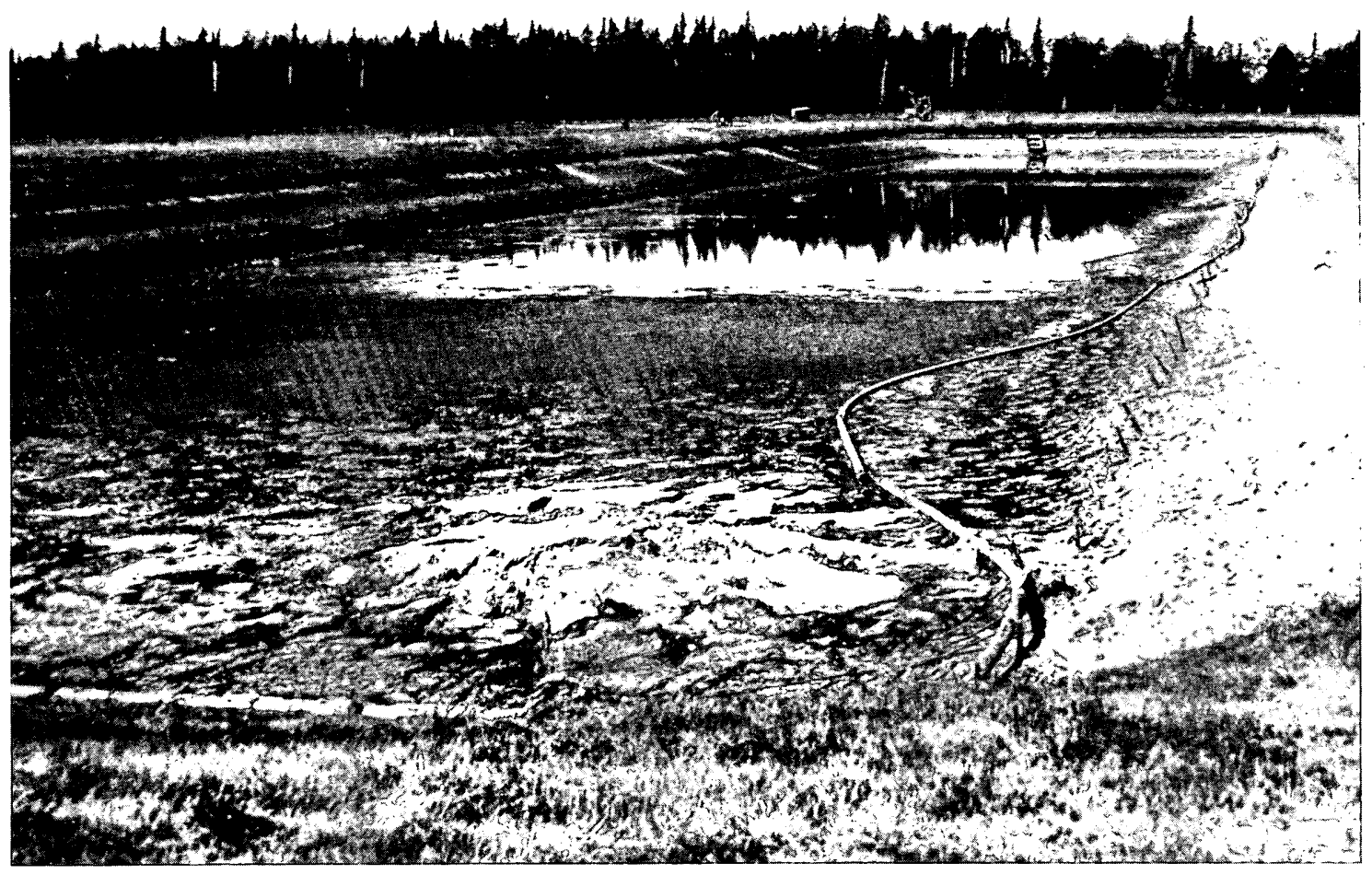

Figure 16. Palmer, Alaska, 1agoon aerated cel1, drained. 
Table 6. Lagoon solids summary.

Total solids

entering

$\operatorname{TSi}\left(\times 10^{3} \mathrm{~kg}\right)$
Total solids present unaccounted for $\operatorname{TSp}\left(\times 10^{3} \mathrm{~kg}\right)$

\begin{tabular}{lrrr} 
Logan & 11135.10 & 1799.3 & 83.84 \\
Corinne & 157.31 & 65.20 & 58.55 \\
Palmer & 229.92 & 232.82 & -1.26 \\
Galena & 140.98 & 4.07 & 97.11 \\
\hline
\end{tabular}

ce11 very seldom reaches $18^{\circ} \mathrm{C}\left(64.6^{\circ} \mathrm{F}\right)$ and on 1 y exceeds $15^{\circ} \mathrm{C}\left(59^{\circ} \mathrm{F}\right)$ occasiona11y.

The annual sludge accumulation rates estimated from the mean sludge depth and operation period listed in Table 5 for the Logan, Corinne, Palmer, and Galena lagoons are $0.68 \mathrm{~cm}(0.27 \mathrm{in.}), 0.84 \mathrm{~cm}(0.33 \mathrm{in.}), 6.7 \mathrm{~cm}(2.64$ in.), and $3.5 \mathrm{~cm}$ (1.38 in.), respectively. The estimated annual accumulation rates for the Utah facultative lagoons are lower than reported values for facultative lagoons in Mississippi and Missouri ( 1.0 to $10.2 \mathrm{~cm}$ ) (Middlebrooks et al. 1965, Howard 1967, Clare et al. 1960). These earlier studies found inorganic matter to be far more significant than organic matter in sludge accumulation. The lower accumulation rate for the Utah lagoons in this study suggests that this was not the case, so that organic matter contributes at least as much to the sludge accumulation as does inorganic matter.

The sludge accumulation rates estimated for Palmer and Galena are within the range of values reported in several studies of sludge accumulation in other Alaskan aerated lagoons. From Table 5, the Palmer volatile solids concentration was $69 \%$ of the total solids and the Galena VS was $49 \%$ of the TS. These VS values are approximately midrange of the previous vS values reported for Alaska aerated lagoons and indicate that organic matter is a substantial contributor to sludge accumulation in these lagoons.

Table 6 presents the results of calculations to estimate the total solids which have entered each lagoon over its operational period, the total solids present at the time of sampling the sludge layer, and the percentage of solids unaccounted for. These values were determined with the following procedure: 


$$
\mathrm{TS}_{\mathbf{i}}=\mathrm{SS}_{\mathbf{i}} \times \mathrm{Q} \times \mathrm{t}(365) 10^{-3}
$$

where

$$
\begin{aligned}
\mathrm{SS}_{\mathrm{i}}= & \text { influent suspended solids concentration, } \mathrm{mg} / \mathrm{L} \\
\mathrm{Q} & =\text { average daily inflow, } \mathrm{m}^{3} / \mathrm{day} \\
\mathrm{t} & =\text { operating time of } 1 \text { agoon, yr } \\
\mathrm{TS}_{\mathbf{i}}= & \text { total solids into lagoon over operating time, } \mathrm{t}, \mathrm{kg} \cdot \\
& \mathrm{TS}=\mathrm{A}_{\mathrm{B}} \mathrm{d} \times \mathrm{TS}_{\mathrm{mc}}\left(10^{-2}\right)
\end{aligned}
$$

where

$$
\begin{aligned}
\mathrm{A}_{\mathrm{B}}= & \text { bottom area of lagoon, } \mathrm{m}^{2} \\
\mathrm{~d}= & \text { depth of sludge layer, } \mathrm{cm} \\
\mathrm{TS}_{\mathrm{mc}}= & \text { measured concentration of total solids in the sludge } \\
& \text { layer, } \mathrm{g} / \mathrm{L} \\
\mathrm{TS}_{\mathrm{p}}= & \text { total solids present in the lagoon at the time of } \\
& \text { sampling, } \mathrm{kg}, \\
& \mathrm{TS}_{\mathrm{u}}=\left(1-\frac{\mathrm{TS}_{\mathrm{p}}}{\mathrm{TS}_{i}}\right) 100
\end{aligned}
$$

where $\mathrm{TS}_{\mathrm{u}}=$ total solids unaccounted for, $\mathrm{kg}$.

It is only possible to speculate on the fate of solids unaccounted for, but some conclusions can be drawn from Table 6. Apparently the solids accumulation in lagoons operating in similar climates can differ greatly. For instance, after five years, the Palmer lagoon had more solids in the sludge layer than theoretically entered the 1agoon. The Galena lagoon had 1ost $97 \%$ of the solids that entered the lagoon over eight years. It is suggested that low water temperature in the sludge layer at Palmer retarded microbial decomposition of the solids, while, at the same time, significant biological activity in the aerated liquid produced additional solids for deposition in the sludge layer. In the case of Galena, it is believed that the lagoon is undersized and that significant short circuiting was taking place, allowing solids to pass out of the lagoon with the effluent. The very thin consistency of the sludge layer at Galena compared to the other lagoons would seem to support the theory that movement of water either by mixing or short-circuiting was too rapid to allow substantial compaction in the sludge layer. The Logan and Corinne lagoons were somewhat more similar in their behavior but not totally predictable. It appears from these data that there is a signifi- 
cant potential for substantial sludge accumulation in cold regions wastewater treatment lagoons.

\section{Lagoon Sludge Characteristics}

Table 7 compares accumulated sludge characteristics for the Logan, Corinne, Palmer and Galena lagoons to typical primary sludge characteristics. Table 8 is a qualitative description of the physical characteristics of the lagoon sludges examined during this study. Table 7 shows that the Logan, Galena and Palmer sludges are quite similar to primary sludge in their characteristics. The main differences are that solids concentrations, both total and volatile, are higher for lagoon sludge than for primary, and fecal coli-

Table 7. Comparison of wastewater lagoon and primary sludge characteristics.

\begin{tabular}{|c|c|c|c|c|c|}
\hline \multirow[b]{2}{*}{$\begin{array}{l}\text { Sludge } \\
\text { parameter }\end{array}$} & \multicolumn{4}{|c|}{ Lagoon } & \multirow{2}{*}{$\begin{array}{c}\text { Typical primary } \\
\text { wast ewater sludge* } \\
\text { Range }\end{array}$} \\
\hline & $\begin{array}{l}\text { Logan, } \\
\text { Utah }\end{array}$ & $\begin{array}{l}\text { Corinne, } \\
\text { Utah }\end{array}$ & $\begin{array}{l}\text { Palme r, } \\
\text { Alaska }\end{array}$ & $\begin{array}{l}\text { Galena, } \\
\text { Alaska }\end{array}$ & \\
\hline Total solids $(\%)$ & 5.9 & 7.7 & 8.6 & 0.89 & $2-8$ \\
\hline Total solids (mg/L) & 58,600 & 76,600 & 85,800 & 9800 & $37,520-65,140$ \\
\hline Volatile solids (\%) & 69.1 & 80.3 & 69.3 & 48.9 & $60-80$ \\
\hline Volatile solids $(\mathrm{mg} / \mathrm{L})$ & 40,470 & 61,520 & 59,490 & 4790 & $28,780-43,810$ \\
\hline $\begin{array}{l}\text { Total organic carbon } \\
(\mathrm{mg} / \mathrm{L})\end{array}$ & 5513 & 6009 & 13,315 & 2651 & ---- \\
\hline $\mathrm{pH}$ & 6.7 & 6.9 & 6.4 & 6.8 & $5-8$ \\
\hline $\begin{array}{l}\text { Fecal coliform } \\
\text { (counts } / 100 \mathrm{~mL} \text { ) }\end{array}$ & $6.7\left(10^{4}\right)$ & $1.0\left(10^{5}\right)$ & $4.1\left(10^{4}\right)$ & $2.5\left(10^{5}\right)$ & $1.3\left(10^{8}\right)-3.3\left(10^{9}\right)$ \\
\hline $\begin{array}{l}\text { Total Kjeldahl } \\
\text { nitrogen (\% of TS) }\end{array}$ & 1.75 & 1.35 & 1.95 & 3.43 & ---- \\
\hline $\begin{array}{l}\text { Total Kjeldahl } \\
\text { nitrogen (mg/L) }\end{array}$ & 1028 & 1037 & 1674 & 336 & $1250-2470$ \\
\hline $\begin{array}{l}\text { Ammonia nitrogen } \\
(\% \text { of } \mathrm{TS})\end{array}$ & 0.12 & 0.09 & 0.11 & 0.45 & ---- \\
\hline Ammonia nitrogen (mg/L) & 72.6 & 68.6 & 93.2 & 44.1 & $19-592$ \\
\hline
\end{tabular}

Table 8. Physical characteristics of the accumulated sludges collected from the Utah and Alaska lagoons.

\begin{tabular}{|c|c|c|c|}
\hline Lagoon & $\begin{array}{r}\text { Sludge } \\
\text { color }\end{array}$ & $\begin{array}{l}\text { Sludge } \\
\text { odor }\end{array}$ & Sludge description \\
\hline Logan, Utah & Dark green & Mild humic & $\begin{array}{l}\text { Non-homogeneous consistency interspersed with matter resembling } \\
\text { yellowed grass clippings. High concentration of household } \\
\text { inorganics (i.e. plastics and metal foils). Stringy, fibrous } \\
\text { matter aggregations thinly distributed. }\end{array}$ \\
\hline Corinne, Utah & olive green & Mild humic & Homogeneous consistency with little noticeable foreign matter. \\
\hline Palmer, Alaska & Black-green & Strong humic & $\begin{array}{l}\text { Nonhomogeneous consistency containing a large amount of stringy, } \\
\text { fibrous matter. Low concentration of household inorganics. }\end{array}$ \\
\hline Galena, Alaska & B1ack & Weak s ewage & $\begin{array}{l}\text { Very homogeneous consistency resembling activated sludge. } \\
\text { Possesses an incoherent floc. Very little noticeable foreign } \\
\text { matter. }\end{array}$ \\
\hline
\end{tabular}


form concentrations are significantly lower. This is reasonable considering the much longer detention time for solids in a lagoon. The longer detention time would provide for some consolidation of solids and die-off of fecal coliform. The Galena sludge appears to be atypical. The reasons for this were not discovered during the course of this study. Table 8 shows that wide variations in the physical appearance of the sludges existed although the sludge characteristics were similar.

\section{Storage Effects on Characteristics}

Large volumes of sludge from the Logan, Corinne, Palmer, and Galena 1agoons were stored at $4^{\circ} \mathrm{C}\left(39.2^{\circ} \mathrm{F}\right)$ to model temperature conditions present at the lagoon bottoms during the winter months. Samples of these sludges were analyzed at least weekly for the parameters listed in Table 7 .

The data collected from the stored lagoon sludge samples over a period of approximately 200 days were analyzed using linear regression to determine the relationship between the parameters and storage time. For total solids (TS), these observations indicate that the data are scattered and no significant change in any of the lagoon sludge TS concentrations occurred over a storage period greater than 200 days at a temperature of approximate $1 \mathrm{y} 4^{\circ} \mathrm{C}$ $\left(39.2^{\circ} \mathrm{F}\right)$. However, VS concentration decreased slightly from 64.4 to $61.5 \mathrm{~g} / \mathrm{L}$ over 265 days for Corinne, and from 61.0 to $54.4 \mathrm{~g} / \mathrm{L}$ over 220 days for Palmer. A linear regression analysis showed only a poor linear relationship between storage time and the reduction in VS.

Table 9 gives results of some additional testing done on ratios of volatile to total solids for the Logan and Palmer Lagoons. These lagoons were picked as being representative of facultative and aerated lagoons. If degradation of accumulated sludge is taking place, the ratio of volatile to total solids should decline over time. Coefficients of determination indicate only weak correlation, but it is interesting to note that the average volatile to total solids ratio over time is very close to the values shown in Table 2 for fresh sludge. Figures 17 and 18 show graphically the weak correlation, but also very little variation over time, indicating that the volatile fraction of the accumulated sludge was undergoing little or no degradation. These figures are representative of plots for all parameters except fecal coliform. The most significant change in any of the parameters over time occurred in the fecal coliform concentrations. A significant decrease in fecal coliform concentrations occurred in all four lagoon sludges. This decrease followed first-order kinetics and suggests that the freshly deposited solids are 
Table 9. Ratios of volatile to total solids for the Logan and Palmer lagoons.

Initial Average $\mathrm{r}^{2} \quad$ slope Intercept

\begin{tabular}{llllll} 
Logan & 69.1 & 66.4 & 0.079 & -0.015 & 68.2 \\
Palmer & 69.3 & 67.4 & 0.461 & -0.202 & 71.2 \\
\hline
\end{tabular}

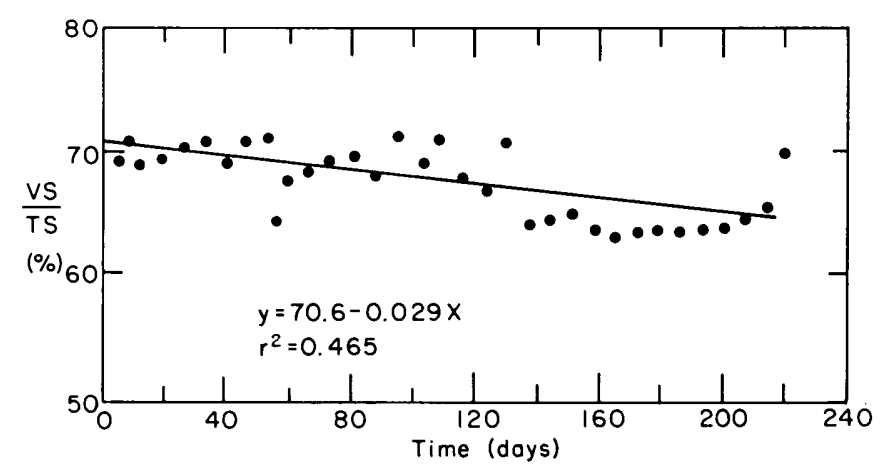

Figure 17. Ratio of volatile to total solids over time for the Logan lagoon.

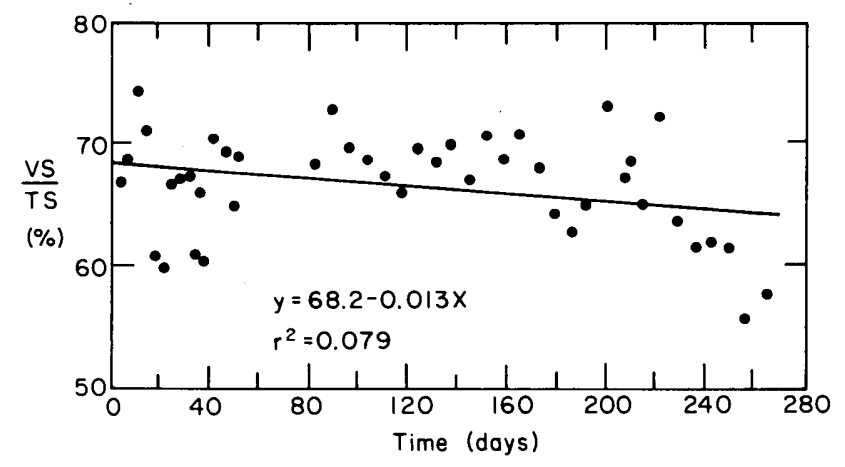

Figure 18. Ratio of volatile to total solids over time for the Palmer lagoon. 
responsible for fecal coliform in the accumulated sludge. Without a replenishing source, the fecal coliform bacteria die off over time even at $4^{\circ} \mathrm{C}$.

The $4^{\circ} \mathrm{C}\left(39.2^{\circ} \mathrm{F}\right)$ storage temperature is very close to the temperature at which water exhibits maximum density. In cold climate lagoons such temperatures will be experienced soon after the fall thermal overturn, and just before surface ice formation commences. It is then very unlikely that the bottom temperature will exceed $4^{\circ} \mathrm{C}\left(39.2^{\circ} \mathrm{F}\right)$ until ice melt and the spring thermal overturn. As a result this is the warmest temperature reached by the bottom sludges during the winter months in both Alaska and Utah as well as similar locations. In Alaska and in more extreme locations, this condition may persist for at least 9 to 10 months and the bottom sludges will never reach the $19^{\circ} \mathrm{C}$ temperatures considered necessary for effective in-situ stabilization.

As indicated above, the test data obtained during the $200+$ day storage period demonstrates little or no change or reduction in the organic solids present in the sludge samples (no significant change for Alaskan sludges and 5 to $11 \%$ reduction in volatile solids for Utah sludges). If it is assumed that these stabilization rates are a function of temperature, that the Alaskan lagoons attain a bottom temperature of about $12^{\circ} \mathrm{C}$ for 2 months each summer and that the Utah sludges remain at $19^{\circ} \mathrm{C}$ for 5 months each summer, it is possible to estimate potential accumulation rates for each case. Assume further that no solids escape in the effluent.

Let $\mathrm{X}=$ suspended solids $(\mathrm{mg} / \mathrm{L})$ at Utah lagoons input each month. Data show that $3 X=$ suspended solids in the $r$ aw wastewater at Alaska lagoons.

Annual input: $\quad \mathrm{Ut} a \mathrm{~h}=12 \mathrm{X}$

$$
\text { Alaska }=36 \mathrm{X}
$$

Winter decomposition in Alaska $=0$.

So: winter accumulation $=(10)(3 \mathrm{X})=30 \mathrm{X}$.

Summer decomposition in Alaska $=\left(\mathrm{X} \% / 12^{\circ} \mathrm{C}=100 \% / 19^{\circ} \mathrm{C}\right)=63 \%$.

Net summer accumulation $=2(3 \mathrm{X})(0.37)=2.2 \mathrm{X}$

Total annual potential accumulation $=(30+2.2)(\mathrm{X})=32.2 \mathrm{X}$.

So: $\quad \begin{aligned} \quad \frac{32.2}{36 \mathrm{X}}= & 89 \% \text { of the solids added to an Alaskan lagoon have the } \\ & \text { potential to remain in the sludge layer. }\end{aligned}$

For Utah: winter decomposition $\simeq 8 \%$

winter accumulation $=(7)(0.92)(X)=6.44 X$

summer decomposition $=100 \%$ 
So: $\frac{6.44}{12}=\begin{aligned} & 54 \% \text { of solids added can potentially stay in the sludge } \\ & \text { layer. }\end{aligned}$

Thus sludge can accumulate in Alaskan lagoons at rates up to $65 \%$ greater than in a northern temperate zone:

$$
\frac{(0.89-0.54)}{0.54}(100)=65 \%
$$

The aeration tubing in the Alaskan lagoons is not believed to have had any significant effect on the settled, accumulated sludge deposits because of the incomplete mixing experienced in such systems. A comparison of the type shown above between the Alaskan and Utah cases should, therefore, be valid. The sludge production during the winter in the aerated lagoons in Alaska would probably be higher than in the ice-covered facultative lagoons in Utah due to the maintenance of aerobic biological reactions in the former case. As a result, the accumulation rate for the Alaskan situation should be even higher than the $72 \%$ calculated above.

Aerobic and Anaerobic Digestion Test.s

Bench-scale digestion studies were conducted in order to examine the aerobic and anaerobic digestion kinetics of the lagoon sludges. None of the basic kinetic relationships commonly used in wastewater calculations were applicable to either the aerobic or anaerobic digestion test data. Additional experimental work will be required for the development of a practical mathematical model that will be generally applicable for prediction of stabilization and accumulation of lagoon sludges. The gas production rates observed during these studies confirmed that the sludge samples were initially unstabilized and similar in character to primary sludge.

Lime Stabilization and Land Application

The lime $\left[\mathrm{Ca}(\mathrm{OH})_{2}\right]$ doses required to raise the $\mathrm{pH}$ value of the lagoon sludges to 12.5 and maintain it at that level for 30 min are presented in Table 10. The initial $\mathrm{pH}$ value of each sludge was approximately 6.5 . The lime requirement for the Galena sludge is considerably higher than that for the other sludges due to the lower solids concentration in the Galena sludge. Dosing requirements on a milligram $\mathrm{Ca}(\mathrm{OH})_{2} / \mathrm{gram}$ TS basis are valid only for sludges with equal solids concentrations; this method of expressing chemical dose is useful in comparing various chemical treatments for a specific sludge. An expression in terms of $\mathrm{g} \mathrm{Ca(OH})_{2} / \mathrm{L}$ of wet sludge is more informa- 
Table 10. $\mathrm{Ca}(\mathrm{OH})_{2}$ dose required to raise sludge $\mathrm{pH}$ value to 12.5 and maintain the $\mathrm{pH}$ at 12.5 for $30 \mathrm{~min}$.

Lagoon sludge

\begin{tabular}{lcccc} 
& Logan & Corinne & Palmer & Galena \\
\cline { 2 - 5 } Initial $\mathrm{pH}$ & 6.2 & 6.7 & 6.2 & 6.5 \\
Final pH & 12.6 & 12.6 & 12.6 & 12.5 \\
TS $(\mathrm{mg} / \mathrm{L})$ & 51,200 & 76,600 & 88,400 & 10,000 \\
& & & & \\
$\mathrm{mg} \mathrm{Ca}(\mathrm{OH})_{2} / \mathrm{g}$ TS & 270 & 180 & 241 & 1500 \\
$\begin{array}{l}\text { g Ca(OH })_{2} / \mathrm{L} \\
\text { of wet sludge }\end{array}$ & 13.8 & 13.8 & 21.3 & 15.0 \\
\hline
\end{tabular}

tive when comparing different sludges. The grams of $\mathrm{Ca}(\mathrm{OH})_{2}$ per liter of wet sludge required to meet the $\mathrm{pH}$ conditions previously stated are reasonably close for the four lagoon sludges. The mean lime dose was $16.0 \mathrm{~g} \mathrm{Ca(OH})_{2} / \mathrm{L}$ $\left.[0.121 \mathrm{~b} \mathrm{Ca(OH})_{2} / \mathrm{gal}\right]$ of wet sludge and the standard deviation is $3.6 \mathrm{~g}$ $\mathrm{Ca}(\mathrm{OH})_{2} / \mathrm{L}\left[0.031 \mathrm{~b} \mathrm{Ca}(\mathrm{OH})_{2} / \mathrm{gal}\right]$ of wet sludge. Typical 1ime dose requirements to adjust and maintain the $\mathrm{pH}$ value at 12.5 for various types of sludge range from 120 to $300 \mathrm{mg} \mathrm{Ca(OH})_{2} / \mathrm{g} \mathrm{TS}\left[0.12\right.$ to $0.301 \mathrm{~b} \mathrm{Ca}(\mathrm{OH})_{2} / 1 \mathrm{~b}$ TS] (EPA $1978 \mathrm{~b})$ or from approximately 4 to $10 \mathrm{~g} \mathrm{Ca(OH})_{2} / \mathrm{L}\left[0.03\right.$ to $0.081 \mathrm{~b} \mathrm{Ca}(\mathrm{OH})_{2} /$ gal] of wet sludge (EPA 1979).

The destruction of pathogens is directly related to the $\mathrm{pH}$ value of the stabilized sludge. For adequate pathogen destruction, the $\mathrm{pH}$ value of limetreated sludge should be maintained at values near 12.0 for nearly $2 \mathrm{hr}$ (Doyle 1967). The decrease in $\mathrm{pH}$ value with time over a 20-day period for the lime-treated Logan, Corinne, Palmer, and Galena sludges is presented in Table 11. The largest decrease in $\mathrm{pH}$ (one $\mathrm{pH}$ unit) occurred in the Corinne sludge during the 20-day period of study. Nineteen days following the application, fecal coliform concentrations in the leachates from limed sludges applied to both sand and soil beds were less than 100 counts/100 mL. The fecal coliform concentrations remained at undetectable levels in the liquid draining from the sand and soil beds even though the $\mathrm{pH}$ of the liquid (leachate) stabilized at about 6.0 for all four lagoon leachates.

The decline in sludge thickness over time for the four lagoon sludges applied to the sand and soil beds is shown in Tables 12 and 13. The changes in moisture content with time in the sludges applied to the sand and soil beds are shown in Tables 14 and 15. These four tables provide an indication of the dewaterability of the lagoon sludges. 
Table 11. Change in $\mathrm{pH}$ value with time for lime treated sludge.

\begin{tabular}{llccc}
$\begin{array}{c}\text { Elapsed } \\
\text { time } \\
\text { (days) }\end{array}$ & \multicolumn{4}{c}{$\mathrm{pH}$} \\
\cline { 2 - 5 } & Logan & Corinne & Palmer & Galena \\
\hline 0 & 12.6 & 12.6 & 12.5 & 12.5 \\
1 & 12.2 & 12.1 & 12.1 & 12.1 \\
2 & 12.4 & 12.3 & 12.4 & 12.4 \\
5 & 12.1 & 12.2 & 12.3 & 12.1 \\
10 & 12.3 & 12.2 & 12.3 & 12.1 \\
20 & 12.0 & 11.6 & 11.8 & 12.0 \\
\hline
\end{tabular}

Table 12. Change in sludge thickness with time for sludges applied to sand beds.

\begin{tabular}{|c|c|c|c|c|}
\hline \multirow{2}{*}{$\begin{array}{c}\text { Elapsed } \\
\text { time } \\
\text { (days) }\end{array}$} & \multicolumn{4}{|c|}{ Sludge thickness $(\mathrm{cm})$ * } \\
\hline & Logan & Corinne & Palmer & Galena \\
\hline 0 & -- & -- & -- & -- \\
\hline 1 & 8.5 & 13.2 & 15.5 & 1.5 \\
\hline 2 & 6.0 & 11.6 & 14.2 & 1.5 \\
\hline 3 & 6.0 & 10.1 & 13.2 & \\
\hline 4 & & 8.8 & 12.6 & \\
\hline 5 & & 7.5 & 12.0 & \\
\hline 6 & & 7.2 & 11.3 & \\
\hline 7 & & 6.6 & 10.7 & \\
\hline 8 & & 5.6 & 10.1 & \\
\hline 9 & & 5.6 & 9.7 & \\
\hline 10 & & & 9.1 & \\
\hline 11 & & & 8.8 & \\
\hline 12 & & & 8.2 & \\
\hline 13 & & & 7.8 & \\
\hline 14 & & & 7.8 & \\
\hline 15 & & & 7.7 & \\
\hline 16 & & & 7.5 & \\
\hline 17 & & & 7.5 & \\
\hline
\end{tabular}


Table 13. Change in sludge thickness with time for sludges applied to soil beds.

\section{Elapsed \\ time} Sludge thickness ( $\mathrm{cm})$ *

(days) Logan Corinne Palmer Galena

$\begin{array}{ccccc}0 & -- & -- & -- & -- \\ 1 & 6.5 & 5.6 & 7.8 & 1.1 \\ 2 & 2.7 & 4.9 & 6.8 & 1.1 \\ 3 & 2.7 & 3.6 & 6.5 & \\ 4 & & 3.3 & 5.9 & \\ 5 & & 3.0 & 5.6 & \\ 6 & & 3.0 & 5.6 & \\ \text { *Applied } & \text { sludge depth }=10 \mathrm{~cm} .\end{array}$

Table 14. Change in moisture content of lime treated sludge over time for sludges applied to sand beds.

\begin{tabular}{ccccc}
$\begin{array}{c}\text { Elapsed } \\
\text { time } \\
\text { (days) }\end{array}$ & \multicolumn{4}{c}{ Moisture content $(\%)$} \\
\cline { 3 - 5 } & Logan & Corinne & Palmer & Galena \\
\hline 0 & 93.4 & 90.8 & 87.4 & 97.0 \\
5 & 70.4 & -- & -- & 70.6 \\
11 & 67.2 & 66.4 & -- & 70.6 \\
15 & 67.2 & 66.4 & -- & 70.6 \\
20 & 64.0 & 60.1 & 66.2 & 69.2 \\
\hline
\end{tabular}

Table 15. Change in moisture content of lime treated sludge over time for sludges applied to soil beds.

\begin{tabular}{ccccc}
\multirow{2}{*}{$\begin{array}{c}\text { Elapsed } \\
\text { time } \\
\text { (days) }\end{array}$} & \multicolumn{4}{c}{ Moisture content $(\%)$} \\
\cline { 2 - 5 } & Logan & Corinne & Palmer & Galena \\
\hline 0 & 93.4 & 90.8 & 87.4 & 97.0 \\
5 & 72.6 & 69.0 & 77.7 & 69.8 \\
11 & 70.3 & 66.1 & 68.2 & 71.2 \\
15 & 70.0 & 62.0 & 65.3 & 68.3 \\
20 & 67.7 & 62.0 & 63.9 & 68.6 \\
\hline
\end{tabular}


The lime-treated Corinne sludge reached a stable depth after nine days on the sand beds and six days on the soil beds. These drying periods for Corinne sludge are significantly longer than the three days required for the Logan sludge to achieve a stable depth on both sand and soil. The different dewatering periods may be related to the dissimilar sludge TS concentrations of Logan and Corinne. The longer dewatering period required for the Corinne sludge to reach a stable depth resulted in lower moisture content of 60.1 and $52.0 \%$ for the sand and soil beds, respectively. The final Corinne sludge moisture content was 4 to $5 \%$ lower than that obtained for the Logan sludge during a 20-day drying period. The final sludge thicknesses for both Logan and Corinne were comparable at roughly 4 and $3 \mathrm{~cm}$ for the sand and soil beds, respectively.

Although the Palmer sludge required nearly twice the time on the sand beds as on the soil beds to reach a stable depth, the moisture contents of the sludge on the sand and soil beds were comparable at the end of 20 days. In fact, all of the sludges on both the sand and soil beds were reasonably close in moisture content with a mean of $65.2 \%$ and standard deviation of 3.3\%. The 7.5- and 5.6-cm final sludge thicknesses on the sand and soil beds, respectively, are due primarily to the higher TS concentration in the Palmer sludge.

These data support findings reported by several researchers and discussed earlier. The high $\mathrm{pH}$ induced by the addition of $\mathrm{Ca}(\mathrm{OH})_{2}$ to the wastewater lagoon sludges resulted in reduction of fecal coliform bacteria concentrations from about $10^{5}$ counts per $100 \mathrm{~mL}$ to less than 100 counts per $100 \mathrm{~mL}$. This reduction in fecal coliform concentrations was evident in the leachate from the sand or soil drying beds as well as in the lime-treated sludge. Application of these data to sludges accumulated at isolated lagoon sites may provide an economical and easily used approach for sludge disposal. Applying the lime-treated sludges to sand or soil drying beds produces a material nearly free of fecal coliforms, and a moisture content of about $60 \%$ after 20 days at $12^{\circ} \mathrm{C}\left(53.6^{\circ} \mathrm{F}\right)$. The problem of ultimate disposal remains, but is considerably eased. Options for ultimate disposal include landfil1ing, landspreading, and incineration with solid waste.

Summary of results

The accumulation of solids in wastewater lagoons is a function of several different parameters and, as such, tends to be site specific. Solids ac- 
cumulation seem to be more severe in colder regions. Design of wastewater lagoons should include consideration of sludge accumulation rates in lagoons operated in similar climates and under similar conditions to those of the lagoon system being planned. An occasional survey of the pond bottom of operating lagoons would provide information on the extent of sludge accumulation and on the potential impact on overall system performance.

The characteristics of the lagoon sludges studied are similar in many ways to those of undigested primary sludges. When stored at $4^{\circ} \mathrm{C}\left(39.2^{\circ} \mathrm{F}\right)$ for longer than 200 days, the lagoon sludges were not modified significantly except for fecal coliform concentrations. The change in concentrations of degradable organic material during the cold storage period was generally of little consequence, although some change did occur in the samples from the Utah lagoons.

The treatment and disposal of accumulated sludges removed from wastewater lagoons can be accomplished by lime addition and air drying on sand and soil beds. Lime doses sufficient to raise sludge $\mathrm{pH}$ to 12.5 effectively reduced fecal coliform concentrations in the sludges and in leachate from the drying beds to less than 100/100 mL. The sludge applied to the drying beds reached a moisture content of about $60 \%$ in less than 20 days at $12^{\circ} \mathrm{C}$ $\left(53.6^{\circ} \mathrm{F}\right)$. The dried sludge was easily handled and suitable for ultimate disposal by landfilling, spreading, or incineration.

\section{CONCLUSIONS}

The sludge layer in selected wastewater lagoons was examined to determine accumulation rate, accumulated sludge characteristics, and stabilization. Also, a brief analysis of lime stabilization and subsequent application to sludge drying beds was performed. Conclusions are presented individually for the four major phases of the study.

\section{Accumulation}

1. The mean sludge depth in the Logan and Corinne, Utah, lagoons was approximately $8 \mathrm{~cm}(3.1 \mathrm{in.})$. The mean sludge depth in the Palmer and Galena, Alaska, lagoons was approximtely $30 \mathrm{~cm}(11.8$ in.). The Alaska lagoons had at least three times more total solids (TS) in the influent than the Utah lagoons. The greatest solids deposition occurred near the inlet. Organic matter was a significant contributor to sludge accumulation. 
2. Approximately equal sludge depths occurred for lagoons of the same type with similar climate, although the operational periods of the lagoons varied by several years.

3. The annual sludge accumulation rates estimated from sludge depth and operation period were as follows: Logan, $0.68 \mathrm{~cm}$; Corinne, $0.84 \mathrm{~cm}$; Palmer, $6.7 \mathrm{~cm}$; and Galena, $3.5 \mathrm{~cm}$.

4. The accumulation pattern of the bottom sludge in the four lagoons studied reflects location of inlet and outlet structures and the configuration of the lagoon. The long narrow lagoon (Palmer) shows less evidence of short-circuited flow than the square configuration (Galena).

5. Some conversion of solids to a gas or liquid byproduct has occurred in the Utah lagoons. A mass of solids equivalent to approximately $23 \%$ of the estimated deposited sludge remains in the Logan lagoon, while a mass equivalent to approximate $1 y 59 \%$ of the deposited sludge remains in the Corinne lagoon. Loss of solids in the effluent is likely to have occurred in the Galena lagoon, with only $3.6 \%$ of the potential deposited sludge remaining. A mass of solids essentially equal to the estimated sludge mass deposited in the Palmer lagoon appears to have remained in place.

\section{Characterization}

1. The TS concentrations in the Logan, Corinne, and Palmer sludges were all similar to the upper limit of reported values for primary sludge. The concentrations $(\mathrm{g} / \mathrm{L})$ of TS in the Logan, Corinne, and Palmer sludges were $58.6,76.6$, and $85.6 \mathrm{~g} / \mathrm{L}$, respectively. The Galena sludge TS concentration of $9.8 \mathrm{~g} / \mathrm{L}$ was radically different from the concentrations in the other three sludges.

2. The Logan, Corinne, Palmer, and Galena sludge volatile solids (VS) concentrations $(\mathrm{g} / \mathrm{L})$ were $40.5,61.5,59.5$ and 4.8 , respectively. As a percentage of TS, these figures are $69.1,80.3,69.3$ and 48.9 , respectively.

3. The $\mathrm{pH}$ values for the Logan, Corinne, Palmer, and Galena lagoon sludges were approximately 6.7 .

4. The fecal coliform concentrations for the Logan, Corinne, Palmer, and Galena lagoon sludges were all similar $\left(10^{5}\right.$ counts per $\left.100 \mathrm{~mL}\right)$. The lagoon fecal coliform concentrations were from $10^{3}$ to $10^{5}$ times lower than those reported for primary sludges. 
5. The decrease in fecal coliform concentrations in the stored Logan, Corinne, Palmer, and Galena lagoon sludges followed first-order kinetics.

6. The change in the Logan, Corinne, Palmer, and Galena lagoon sludge TS concentrations over approximately 200 days of storage at $4^{\circ} \mathrm{C}\left(39.2^{\circ} \mathrm{F}\right)$ was essentially undetectable ( $95 \%$ confidence leve 1 ). For the same storage period and temperature, the Logan, Corinne, and Galena lagoon sludge VS concentrations experienced no change at the $95 \%$ confidence level. The Palmer lagoon sludge VS concentration underwent a statistically significant ( $95 \%$ confidence leve 1 ) decrease ( $12 \%$ ) over the 200-day storage period at a temperature of $4^{\circ} \mathrm{C}\left(39.2^{\circ} \mathrm{F}\right)$.

7. The changes that occurred in the characteristics of the lagoon sludges during storage indicate that the sludges were not stabilized but, rather, are similar to primary sludge.

Lime Stabilization and Land Application

1. The mean lime dose required to raise the $\mathrm{pH}$ from approximately 6.5 to approximately 12.5 and maintain a $\mathrm{pH}$ of 12.5 for $30 \mathrm{~min}$ in all four sludges was $16.0 \mathrm{~g} \mathrm{Ca}(\mathrm{OH})_{2} / \mathrm{L}[0.12 \mathrm{lb} \mathrm{Ca(OH})_{2} / \mathrm{gal}$. $]$ of wet sludge with a standard deviation of $3.6 \mathrm{~g} \mathrm{Ca}(\mathrm{OH})_{2} / \mathrm{L}\left[0.031 \mathrm{~b} \mathrm{Ca}(\mathrm{OH})_{2} / \mathrm{ga}\right.$. $]$ of wet sludge.

2. Following a 20-day drying period on sand and soil beds, the pH value of the lime-stabilized lagoon sludges dropped less than one pH unit.

3. Fecal coliform concentrations were reduced to undetectable levels in the lime-stabilized lagoon sludges.

4. The fecal coliform concentration in the liquid passing the sand and soil beds remained at undetectable levels over the 20-day sampling period with the liquid $\mathrm{pH}$ value near 6.0 for the 20-day period.

5. Although sludge drying occurred at different rates among the four sludges, at the end of the 20-day sampling period the mean sludge moisture content was $65.2 \%$ for all four lagoon sludges on both the sand and soil beds. The standard deviation of the sludge moisture content at the end of the 20-day period was $3.3 \%$.

6 . Lime treatment of sludges removed from lagoons will eliminate pathogens and odors so that the sludges are safe and aesthetically acceptable to handle and transport for land application or other disposal methods. 


\section{LITERATURE CITED}

Bartsch, E.H. and C.W. Randa11 (1971) Aerated lagoons - A report on the state-of-the-art. Journal, Water Pollution Control Federation, 43(4):699-708.

Bishop, S.L. and G.P. Fulton (1968) Lagooning and freezing for disposal of water plant sludge. Public Works, 99(6):94-96.

Boulier, G.A. and T.J. Atchison (1975) Practical Design and Application of the Aerated-Facultative Lagoon Process. Hinde Engineering Co., Highland Park, Illinois, 33 pp.

Cheng, D., D.M. Updegraff and L.W. Ross (1970) Sludge dewatering by highrate freezing at small temperature differences. Environmental Science and Technology, 4(12):1145-1147.

Christianson, C.D. 1976. Cold climate aerated lagoons. Second International Symposium on Cold Regions Engineering, University of A1aska, Fairbanks, Aug. 12-14. 597 p p.

Christianson, C.D. and H.S. Coutts (1979) Performance of aerated lagoons in northern climates. EPA-600/3-79-003. College, Alaska. 175 p.

Clare, H.C., J.K. Nee1 and C.A. Monday, Jr. (1960) Studies of raw sewage lagoons at Fayette, Missouri, 1958-1959 with a resume of 1957-1958 operations. Symposium on Waste Stabilization Lagoons, Kansas City, Missouri, Aug. 1-5. $214 \mathrm{pp}$.

Clark, S.W., H.J. Coutts and R. Jackson (1970) Alaska sewage lagoons. In Second International Symposium for Waste Treatment Lagoons. Federal Water Quality Administration, Washington, D.C., Pp. 221-230.

Dawson, R.N. and J.W. Grainge (1969) Proposed design criteria for wastewater lagoons in arctic and subarctic regions. Journal, Water Pollution Contro1 Federation, 41(2):237--246.

Doyle, C.B. (1967) Effectiveness of high pH for destruction of pathogens in raw sludge filter cake. Journal, Water Pollution Control Federation, 39(8):1403-1409.

EPA (1975) Wastewater Treatment Ponds. EPA-430/9-74-011. Washington, DC. 14 p.

EPA (1978a) Sludge Treatment and Disposal - Sludge Treatment - Volume 1. EPA-625/4-78-012. Cincinnati, Ohio. 140 pp.

EPA (1978b) Sludge Treatment and Disposal - Sludge Disposal - Volume 2 . EPA-625/4-78-012. Cincinnati, Ohio. 155 pp.

EPA (1979) Process Design Manual for Sludge Treatment and Disposal. EPA-625/1-79-011. Cincinnati, Ohio. $996 \mathrm{pp}$.

Evans, J.0. (1969) Ultimate sludge disposal and soil improvement. Water and Waste Engineering, 6(6):45-47. 
Farrel1, J.B. (1974) Overview of sludge handling and disposal. Proceedings, National Conference on Municipal Sludge Management, Information Transfer, Inc, Washington, D.C., 218 pp.

Farre11, J.B., J.E. Smith, Jr., S.W. Hathaway and R.B. Dean (1974) Lime stabilization of primary sludges. Journal, Water Pollution Control Federation, 46(1):113-122.

Girling, R.M., A.R. Pick and D.W. Van Es (1974) Further field investigation on aerated lagoons in the City of Winnipeg. In Symposium on Wastewater Treatment in Cold Climates. Envi ronmental Protection Service, Environment Canada, EPS 3-WP-74-3. 595 p.

Gloyna, E.F. (1971) Wastewater Stabilization Ponds. WHO, Geneva, Switzerland. Monograph Series No. $60.170 \mathrm{p}$.

Heckroth, C. (1971) Here comes the sludge, are you ready for it? Water and Waste Engineering, 8(11):40-44.

Howard, D.E. (1967) A study of solids deposition in lagoons. M.S. thesis, Univ. Missouri, Columbia, Missouri. $52 \mathrm{pp}$.

Huray, A. (1977) Aerated facultative lagoons. Division of Water Quality, California State Water Resources Control Board, 30 pp.

Katz, W.J. and D.G. Mason (1970) Freezing conditions used to condition activated sludge. Water and Sewage Works, $117(4): 110-114$.

Lawson, P.D. (1977) Sludge handling and disposal problems in the Prairie Provinces. In Technology Transfer Seminar on Sludge Handling and Disposal. Envi ronment Canada, Calgary, Alberta. Feb. 16-18. 550 p.

Leclerc, H. and P. Brouzes (1973) Sanitary aspects of sludge treatment. Water Resources, 7(3):355-360.

Logsdon, G.S. and E. Edgerly, Jr. (1971) Sludge dewatering by freezing. Journal, Water Pollution Control Federation, 63:(11):734-740.

Marais, G.V.R. (1970) Dynamic behavior of oxidation ponds. In Second International Symposium for Waste Treatment Lagoons. Kansas City, Missouri, June 23-25. 404 pp.

Metcalf and Eddy, Inc. (1979) Wastewater Engineering: Treatment, Disposa1, Reuse. 2nd Ed., McGraw-Hill, New York,. 920 pp.

Middlebrooks, E.J., A.J. Panagiotou and H.K. Williford (1965) Sludge accumulation in municipal sewage lagoons. Water and Sewage Works, $12(2): 63-68$.

Morrison, S.M., K.L. Martin and D.E. Humble (1973) Lime disinfection of sewage bacteria at low temperature. EPA 660/2-73-017. Arctic Environ. Research Lab., College, Alaska, 90 pp. 
Noland, R.F. and J.D. Edwards (1977) Stabilization and disinfection of wastewater treatment plant sludges. Handout at Sludge Treatment and Disposal Seminar, EPA-ERIC (unpublished), $160 \mathrm{pp}$.

Oswald, W.J. (1968) Advances in anaerobic pond systems design. In Advances in Water Quality Improvement, Water Quality Symposium No. 1 . Univ. of Texas Press. Austin, Texas, 513 pp.

Parker, C.D. and G.P. Skerry (1968) Function of solids in anaerobic lagoon treatment of wastewater. Journal, Water Pollution Control Federation, 40(2):192-204.

Pauls rud, B. and A.S. Eikum (1975) Lime stabilization of sewage sludges. Water Resources, 9(3):297-305.

Pick, A.R., G.E. Burns, D.W. Van Es and R.M. Girling (1970) Evaluation of aerated lagoons as a sewage treatment facility in the Canadian Prairie Provinces. In International Symposium on Water Pollution Control in Cold Climates. Univ. Alaska, Fairbanks, Alaska, July 22-25. 332 pp.

Ramirez, A. and J.F. Malina, Jr. (1980) Chemicals disinfect sludge. Water and Sewage Works, $127(4): 52-54$.

Reid, L.C., Jr. (1970) Design and operation considerations for aerated lagoons in the Arctic and Subarctic Environmental Engineering Station. Arctic Health Resource Center, Environmental Health Ser., USPH, DHEW, College, Alaska. Report No. 102, 32 pp.

Rush, R.J. and A.R. Stickney (1979) Natural freeze-thaw sewage sludge conditioning and dewatering. Training and Technology Division (Water), Environ. Protection Ser., Environment Canada, Ottawa, Ontario. Project No. EPs 4-WP-70-1. 40 pp.

Schroeder, W.H. and D.B. Cohen (1977) Overview of current sludge treatment and disposal practices. In Technology Transfer Seminar on Sludge Handling and Disposa1, Calgary, Alberta, February 16-18, 550 pp.

Stander, G.J., P.G.J. Merring, R.J.L.C. Drews and H. Van Eck (1970) A guide to pond systems for wastewater purification. In Developments in Water Quality Research. Ann Arbor Science, Ann Arbor, Michigan. 312 pp.

Tilsworth, T. (1972) Sludge production and disposal for small cold climate bio-treatment plants. Institute of Water Resources. Univ. Alaska, Fairbanks, Alaska. 43 pp.

U.S. Army (1975) AFSS Lagoon Study. Unpublished Report. U.S. Army Corps Engineers, Alaska District, 24 pp.

Vesilind, P.A. (1974) Treatment and Disposal of Wastewater Sludges. Ann Arbor Science Publishers, Inc., Ann Arbor, Michigan, 236 pp.

Wang, M.H., L.K. Wang, G.G. Perry, III and R.C.M. Cheung (1978) General theories of chemical disinfection and sterilization of sludge: Part 3. Water and Sewage Works, 125(9):99-104. 
Water and Sewage Works (1970) Dredge used to clean sludge lagoons. Water and Sewage Works, $117(12): 417$. 